\title{
Revision of the Neotropical genus Desmopsis (Annonaceae)
}

\author{
G.E. Schatz' ${ }^{1}$, P.J.M. Maas², H. Maas-van de Kamer², L.Y.T. Westra², J.J. Wieringa²
}

Key words

Annonaceae descriptions Desmopsis morphology Neotropics phylogeny taxonomy vernacular names

\begin{abstract}
A taxonomic revision of the genus Desmopsis is presented. Within the genus Desmopsis 25 species are recognized, 9 of which are new, with one new combination. Distinguishing morphological characteristics are discussed, and a dichotomous key to all species is given. The species treatments include descriptions, full synonymy, geographical and ecological notes, vernacular names, and taxonomic notes. Distribution maps are presented of all species, and a complete identification list of exsiccatae examined is included.
\end{abstract}

Published on 26 June 2018

\section{INTRODUCTION}

While working in the Office of Economic and Systematic Botany of the Bureau of Plant Industry within the United States Department of Agriculture during the early 20th century, William E. Safford (1859-1926) conducted taxonomic research on various groups including Acacia, Cactaceae, and Annonaceae. Among the six genera of Annonaceae Safford described, only two currently remain accepted: Desmopsis and Fusaea. Safford (1916) proposed the genus Desmopsis to accommodate three previously described species along with two newly described species from Central America with leaf-opposed flowers borne on bracteate pedicels, and apocarpous fruits consisting of stipitate, berry-like monocarps. Among his series of revisions of Neotropical genera of Annonaceae, Fries (1930) recognized 8 species of Desmopsis. Subsequent descriptions of new species of Desmopsis by Fries (1931, 1941, 1948), Lundell (1939), and Standley (1932, and in Standley \& Steyermark 1944) brought the total number of Desmopsis species recognized by Fries (1959) to 16. Since then, several additional species have been described (Lundell 1974, Erkens et al. 2006, Jiménez-Ramírez \& González-Martínez 2016), and several nomenclatural rearrangements have been proposed (Maas et al. 1994). Based on the examination of over 1000 exsiccatae, the current work recognizes 25 species of Desmopsis, including one new combination and 9 new species.

\section{GENERAL MORPHOLOGY}

\section{Habit}

Species of Desmopsis are shrubs to small trees usually less than $10 \mathrm{~m}$ tall, rarely to $20 \mathrm{~m}$ tall in $D$. dukei and $D$. schippii. The main trunk is slender in species for which diameter has been recorded, usually less than $10 \mathrm{~cm}$ diam, rarely to $30 \mathrm{~cm}$ diam in D. schippii.

\footnotetext{
Missouri Botanical Garden, 4344 Shaw Blvd., St. Louis, Missouri, 63110, USA; corresponding author e-mail: george.schatz@mobot.org

2 Naturalis Biodiversity Center, section Botany, P.O. Box 9517, 2300 RA Leiden, The Netherlands.
}

\section{Leaves}

Leaves are simple, entire, petiolate, and estipulate, and arranged alternately in a single plane along lateral branches (distichous). Petioles are usually short, less than $10 \mathrm{~mm}$ long, the longest petioles found in $D$. biseriata $(5-15 \mathrm{~mm}), D$. wendtii (7-15 mm), and $D$. verrucipes $(5-20 \mathrm{~mm})$. The shape of the lamina is narrowly elliptic to elliptic, occasionally narrowly ovate to ovate or obovate, or rarely rhombic-obovate to circular in $D$. neglecta. The texture varies from membranous to chartaceous to rarely subcoriaceous ( $D$. neglecta), the surface dull to shiny and often smooth, but occasionally verruculose above and below, with glandular oil bodies evident in $D$. guerrerensis. The lamina is usually $10-20 \mathrm{~cm}$ long, with small leaves occurring in D. lanceolata $(4-10 \mathrm{~cm}), D$. neglecta $(2-8 \mathrm{~cm})$, and $D$. talamancana $(5-9 \mathrm{~cm})$, and especially large leaves occurring in $D$. biseriata $(17-42 \mathrm{~cm}), D$. heteropetala $(15-40 \mathrm{~cm})$, $D$. nigrescens $(15-30 \mathrm{~cm})$, and $D$. verrucipes $(16-40 \mathrm{~cm})$. The base of the lamina is attenuate to acute to less often obtuse, or rarely distinctly cordate in $D$. heteropetala. The apex of the lamina is generally acute to acuminate, the acumen 2-25 $\mathrm{mm}$ long, or rarely obtuse, with the extreme tip often distinctly obtuse to rounded. The primary vein is distinctly impressed or sometimes flat above. The venation is brochidodromous with $5-15$ secondary veins per side, the tertiary venation reticulate to rarely percurrent. The indument on young branches, petioles, and lamina is composed of simple appressed or erect hairs. In most species of Desmopsis the lower side of the leaves is glabrous or nearly so, less often sparsely covered with appressed hairs, or densely covered with long-persisting, erect hairs in $D$. confusa, $D$. dukei, $D$. oerstedii, and $D$. trunciflora.

\section{Inflorescences}

Inflorescences are terminal rhipidia, usually appearing leafopposed by the overtopping of the renewal shoot and mostly bearing 1 or 2 flowers (rarely up to 15); inflorescences are sometimes borne on the main trunk, occasionally so in $D$. confusa, D. dolichopetala, D. schippii, D. subnuda, and D. verrucipes, and exclusively so in $D$. wendtii. The pedicel (here measured as the entire stalk both below and above the articulation, i.e., including the peduncle) bears a basal bract at the articulation and a second bract higher up toward the flower, the bracts either 
foliaceous ('leafy') or 'scale-like'. Pedicels vary in length from 5 to $110 \mathrm{~mm}$ (lengthening in fruit to $140 \mathrm{~mm}$ ), with the shortest pedicels found in $D$. brachypoda (10-15 mm), D. dukei (10-16 $\mathrm{mm})$, and $D$. neglecta (5-15 $\mathrm{mm})$.

\section{Flowers}

Flowers are pendant, with 3 free sepals and 6 free petals in 2 equal to subequal, or rarely unequal $(D$. heteropetala and $D$. wendtii) whorls, the aestivation valvate. The torus is convex and densely covered with erect hairs. Petals are green to cream or white, or most often yellow, sometimes with a red blotch at the base inside, and lack evident venation. Stamens are numerous, the anthers latrorse to extrorse, with a very short filament and a discoid connective apex. Carpels are free, generally numerous, the stigma is sessile, depressed spherical to club-shaped to obpyriform, and densely covered with very short, erect hairs. Ovules (1-17) are lateral in either one or two $(D$. biseriata, $D$. heteropetala, $D$. talamancana, and $D$. wendtii) rows.

\section{Fruit}

Fruits are apocarpous, consisting of $2-40$, free, stipitate or rarely subsessile, berry-like monocarps. The stipe varies in length from < 1 to $35 \mathrm{~mm}$, with short stipes found in $D$. dolichopetela (3-6 mm), D. lanceolata $(2-5 \mathrm{~mm}), D$. mexicana $(3-5 \mathrm{~mm})$, $D$. neglecta $(<1-3 \mathrm{~mm}), D$. schippii $(1-5 \mathrm{~mm})$, D. subnuda (3-7 mm), D. talamancana (3-7 mm), and D. trunciflora (2-3 $\mathrm{mm}$ ). The monocarps vary in size from 5 to $45 \mathrm{~mm}$ long by 5 to $27 \mathrm{~mm}$ in diameter, and in shape from spherical to ellipsoid to oblongoid. Upon drying, the monocarps are sometimes slightly to strongly constricted between the seeds. The wall of the monocarps is usually thin $(0.1-1 \mathrm{~mm}$ thick), but especially thick monocarp walls are found in $D$. heteropetala $(2-4 \mathrm{~mm})$, $D$. oerstedii (2-4 mm), and $D$. talamancana (1-1.5 mm). Seeds vary in number from 1 to 14 , and are of various shapes depending on the number of seeds in the monocarp, their position, and whether there are one or two rows. Seeds in monocarps with only a single seed are spherical or subspherical to ellipsoid; seeds in monocarps with two seeds, or the seeds at either end in monocarps with three or more seeds in a single row are hemispherical; seeds in middle positions of monocarps with three or more seeds in a single row are discoid; seeds in the middle positions of monocarps with seeds in two rows are hemidiscoid; and seeds at either end in monocarps with seeds in two rows are quartispherical. Seeds bear a distinct encircling raphe, and the seed coat can be either smooth, grooved and/or pitted with the endosperm ruminations peg-shaped to lamellate.

\section{THE PHYLOGENETIC POSITION OF DESMOPSIS WITHIN ANNONACEAE}

Desmopsis has been placed in tribe Miliuseae of subfamily Malmeoideae (Chatrou et al. 2012). A recent plastid phylogeny of tribe Miliuseae (Chaowasku et al. 2014) recovered Desmopsis in a clade of Mesoamerican taxa sister to Stenanona, the two of them in turn sister to an undescribed species from Mexico also referred to Desmopsis. Together, Desmopsis, Stenanona, and the undescribed species are sister to the other Mesoamerican genera Sapranthus (Schatz et al. 2018) and Tridimeris. This Mesoamerican clade of Miliuseae is nested in a larger clade of Asian genera, and most closely related to an undescribed genus from Thailand, and Meiogyne. Desmopsis was distinguished from Stenanona in a revision of the latter genus (Schatz \& Maas 2010) by its thicker, stiffer petals lacking venation, and its disulculate boat-shaped pollen (vs inaperturate globose pollen in Stenanona). A more recent molecular phylogenetic study of the Neotropical Miliuseae (Ortiz-Rodriguez et al. 2016), which formally described the clade as subtribe Sapranthinae, has revealed the possibility that Desmopsis and Stenanona as currently circumscribed may not be monophyletic, and might best be treated as a more broadly circumscribed Desmopsis, or alternatively be carved into multiple genera. However, some of the branches and nodes in the phylogeny lack adequate support values, nor is the taxon sampling comprehensive. Until the molecular phylogenetic results are fully resolved, the current revision treats Desmopsis in its traditional sense.

\section{TAXONOMIC TREATMENT}

\section{Desmopsis}

Desmopsis Saff. (1916) 184. - Type: Desmopsis panamensis (B.L.Rob.) Saff.

Trees or shrubs. Indument composed of simple hairs or absent. Young twigs terete, densely to sparsely covered with erect to appressed hairs, soon becoming glabrous in many species. Leaves distichous, simple, entire, petiolate, estipulate; lamina elliptic to narrowly elliptic, sometimes narrowly ovate or obovate, or rarely rhombic to circular, membranous to chartaceous, sometimes verruculose, upper side glabrous to less often sparsely covered with appressed hairs, lower side glabrous or sparsely to densely covered with appressed or erect hairs, base attenuate, acute or obtuse, rarely cordate, apex acute to acuminate, rarely obtuse, the extreme tip often obtuse or rounded, primary vein impressed to flat above, venation brochidodromous with 5-15 secondary veins per side, tertiary venation reticulate to sometimes percurrent. Flowers bisexual, 3-merous, in 1-few-flowered (rarely to 15-flowered) terminal inflorescences borne leaf-opposed, or sometimes produced from the main trunk; pedicels with an articulation below the middle, with one bract below the articulation, often leafy or sometimes scale-like, and a second bract above the articulation, usually scale-like but sometimes leafy; pedicels and outer side of bracts, sepals and petals glabrous to sparsely covered with appressed to erect hairs; flower buds conical; sepals 3 , free, valvate; petals 6 , free, in two equal to subequal whorls, rarely unequal, valvate, much longer than sepals, green, maturing cream to white, or more often yellow, sometimes with red blotch at the base inside; stamens numerous, with very short filaments, the anther not septate, the apex of the connective discoid, papillate to covered with very short, erect hairs; pollen disulculate, boat-shaped, exine verrucate; staminodes absent; carpels several to numerous, free, ovules 1-17, lateral, in one or less often two rows, stigma sessile, depressed globose to club-shaped to obpyriform. Fruit apocarpous, consisting of several to numerous, indehiscent, stipitate, fleshy, spherical to ellipsoid to oblongoid to ovoid monocarps, stipes to $35 \mathrm{~mm}$ long, rarely monocarps subsessile. Seeds 1-14, discoid, sometimes spherical to ellipsoid, hemispherical, hemidiscoid or quartispherical, brown, surface smooth, grooved or pitted, endosperm ruminations peg-shaped to lamellate.

Distribution - 25 species from Mexico to Colombia, and Cuba.

Habitat \& Ecology - In evergreen to semi-evergreen to rarely deciduous forest. From sea level to $2000 \mathrm{~m}$.

Note - The genus was given its name because of its resemblance to the Old World genus Desmos.

\section{KEY TO THE SPECIES}

1. Lamina densely covered with long-persisting, erect hairs below . . . . . . . . . . . . . . . . . . . . . . 2

1. Lamina glabrous or rather densely to sparsely covered with appressed hairs below, usually glabrescent . . . . . 5

2. Monocarps $5-10 \ldots \ldots \ldots \ldots \ldots \ldots \ldots \ldots \ldots$

2. Monocarps $10-30 \ldots \ldots \ldots \ldots \ldots \ldots \ldots \ldots \ldots$ 
3. Stipes 5-12 mm long; wall of monocarps $2-4 \mathrm{~mm}$ thick. Costa Rica . . . . . . . . . . . . . . . . . . . 17. D. oerstedii

3. Stipes 2-3 mm long; wall of monocarps $0.2-0.5 \mathrm{~mm}$ thick. - Mexico . . . . . . . . . . 22. D. trunciflora

4. Pedicels $10-16 \mathrm{~mm}$ (to $25 \mathrm{~mm}$ in fruit) long; stipes $12-25$ $\mathrm{mm}$ long. - Costa Rica, Panama, Colombia 7. D. dukei

4. Pedicels $50-70 \mathrm{~mm}$ (to $120 \mathrm{~mm}$ in fruit) long; stipes $5-15$ mm long. - Costa Rica, Panama ..... . 5. D. confusa

5. Ovules/seeds in two rows $\ldots \ldots \ldots \ldots \ldots \ldots \ldots$

5. Ovules/seeds in one row. . . . . . . . . . . . 9

6. Inflorescences strictly trunciflorous. - Mexico........ 25. D. wendtii

6. Inflorescences leaf-opposed. - Costa Rica, Panama . 7

7. Base of lamina cordate. - Costa Rica10. D. heteropetala

7. Base of lamina attenuate to obtuse . . . . . . 8

8. Lamina $17-42$ by $9-17 \mathrm{~cm}$; basal bract scale-like. - Costa Rica, Panama . . . . . . . . . . . . 2. D. biseriata

8. Lamina $5-9$ by $2-5 \mathrm{~cm}$; basal bract leafy. - Costa Rica 21. D. talamancana

9. Basal bract scale-like, only $1-3 \mathrm{~mm}$ long . . . . . . 10

9. Basal bract leafy, at least $4 \mathrm{~mm}$ long . . . . . . . . 18

10. Sepals larger, $3-20 \mathrm{~mm}$ long $\ldots \ldots \ldots \ldots \ldots \ldots 11$

10. Sepals small, up to $3 \mathrm{~mm}$ long but usually less. . . . . 14

11. Lamina $7-16$ by $2.5-7 \mathrm{~cm}$; secondary veins $6-10$ per side; pedicels $10-20 \mathrm{~mm}$ long. . . . . . . . . . . . . 12

11. Lamina $8-40$ by $3-17 \mathrm{~cm}$; secondary veins $7-14$ per side; pedicels $10-50 \mathrm{~mm}$ long. . . . . . . . . . . . 13

12. Lamina rather densely to sparsely covered with appressed hairs below; pedicels 10-15 mm long. - Panama.....

3. D. brachypoda

12. Lamina glabrous below except for appressed hairs along the primary vein; pedicels $15-50 \mathrm{~mm}$ long. - Mexico . .

20. D. subnuda

13. Young twigs sparsely covered with appressed hairs; lamina non-verrucose; monocarps spherical to ellipsoid, $8-15$ by 6-12 mm; seeds 1-2 per monocarp. - Belize, Guatemala................... 8. D. erythrocarpa

13. Young twigs glabrous; lamina densely verruculose on both sides; monocarps ellipsoid-oblongoid to spherical, 8-30 by $8-15 \mathrm{~mm}$; seeds 2-7 per monocarp. - Costa Rica, Panama . . . . . . . . . . . . . . 24. D. verrucipes

14. Lamina rhombic-obovate to circular, $2-8$ by $1.5-5 \mathrm{~cm}$, subcoriaceous; pedicels $5-15 \mathrm{~mm}$ long. - Cuba.

15. D. neglecta

14. Lamina narrowly elliptic to elliptic to narrowly ovate-elliptic, $7-22$ by $3-9 \mathrm{~cm}$, membranous to chartaceous, pedicels 10-90 mm long. - Mesoamerica, Colombia . . . . . 15

15. Stipes of monocarps $5-15 \mathrm{~mm}$ long; monocarps $2-4$. Colombia ................. . 4. D. colombiana

15. Stipes of monocarps 1-6 mm long; monocarps 2-12 16

16. Monocarps $3-10,10-18$ by $8-10 \mathrm{~mm}$; inflorescences leafopposed. - Mexico . . . . . . . . . . 13. D. mexicana

16. Monocarps $2-12,10-45$ by $10-25 \mathrm{~mm}$; inflorescences leafopposed or produced from the main trunk. . . . . . . 17

17. Lamina with 9-12 secondary veins per side; monocarps to $45 \mathrm{~mm}$ long; seeds $20-21$ by $6-10 \mathrm{~mm}$. - Honduras 6. D. dolichopetala

17. Lamina with 6-8 secondary veins per side; monocarps to $27 \mathrm{~mm}$ long; seeds $8-15$ by $3-5 \mathrm{~mm}$. - Mexico, Belize, Honduras, Nicaragua, Costa Rica, Panama, Colombia . . . . . . . . . . . . . . . . . 19. D. schippii

18. Young twigs densely (to sparsely) covered with persistent erect and/or appressed hairs . . . . . . . . . . 19
18. Young twigs glabrous or initially rather densely to sparsely covered with appressed hairs, soon glabrous . . . . . 22

19. Pedicels $15-20 \mathrm{~mm}$ long, to $25 \mathrm{~mm}$ in fruit; stipes of monocarps $2-5 \mathrm{~mm}$ long; lamina $4-10$ by $1-3.5 \mathrm{~cm}$. - Mexico, Guatemala . . . . . . . . . . . . . . . . . 11. D. lanceolata

19. Pedicels $15-70 \mathrm{~mm}$ long, to $100 \mathrm{~mm}$ in fruit; stipes of monocarps $3-13 \mathrm{~mm}$ long; lamina $7-20$ by $2.5-8 \mathrm{~cm} \ldots 20$

20. Sepals $6-12 \mathrm{~mm}$ long; petals equal. - Mexico ...... $\ldots \ldots \ldots \ldots \ldots \ldots \ldots$. . . . . . . uxpanapensis

20. Sepals $2-6 \mathrm{~mm}$ long; petals subequal . . . . . . 21

21 . Lamina generally larger $(10-20$ by $4-8 \mathrm{~cm})$, sparsely covered with appressed and erect often curly hairs below; margins of petals strongly revolute; monocarps 5-25, generally longer (10-30 mm long). - Panama

18. D. panamensis

21. Lamina generally smaller $(7-12$ by $2.5-6 \mathrm{~cm})$, glabrous below except with appressed hairs along the primary vein; margins of petals not revolute; monocarps $2-8$, generally shorter (8-17 mm long). - Mexico . . . . 20. D. subnuda

22. Lamina generally smaller $(4.5-16$ by $2-5 \mathrm{~cm}) \ldots \ldots 23$

22. Lamina generally larger $(6-30$ by $2-14 \mathrm{~cm})$, with at least some leaves wider than $5 \mathrm{~mm}$. . . . . . . . . . . . 24

23. Sepals 7-9 mm long, persistent in fruit; petals $5.5-10.7$ by $2.7-3.3 \mathrm{~mm}$; monocarps $5-10$, not constricted between the seeds. - Mexico . . . . . . . . . 9. D. guerrerensis

23. Sepals $3-4 \mathrm{~mm}$ long, not persistent in fruit; petals $11-25$ by $5-9 \mathrm{~mm}$; monocarps $10-30$, usually strongly constricted between the seeds. - El Salvador to Panama . . . . . .

1. D. bibracteata

24. Young twigs initially sparsely to rather densely covered with appressed hairs, soon glabrous; upper bract leafy; apex of petals incurved; monocarps sparsely covered with appressed hairs. - Nicaragua, Costa Rica, Panama. . .

14. D. microcarpa

24. Young twigs glabrous; upper bract scale-like; apex of petals not incurved; monocarps glabrous . . . . . . . . 25

25. Lamina generally larger ( $15-30$ by $5-14 \mathrm{~cm}$ ), turning black upon drying; secondary veins 9-12 per side; sepals accrescent and often persistent in fruit, to $22 \mathrm{~mm}$ long; wall of monocarps $0.5-1 \mathrm{~mm}$ thick. - Panama . . . . . . . . . .

16. D. nigrescens

25. Lamina generally smaller ( $8-22$ by $3-8 \mathrm{~cm}$ ), not turning black upon drying; secondary veins $6-8$ per side; sepals not accrescent nor persistent in fruit, $3-8 \mathrm{~mm}$ long in flower; wall of monocarps $0.3-0.5 \mathrm{~mm}$ thick. - Costa Rica, Panama ... . . . . . . . . . 12. D. maxonii

\section{Desmopsis bibracteata (B.L.Rob.) Saff. - Fig. 1a; Map 1}

Desmopsis bibracteata (B.L.Rob.) Saff. (1916) 190, t. 9. — Unona bibracteata B.L.Rob. (in Robinson \& Greenman 1895) 175. - Type: Wright 1 (holo GH; iso US 2 sheets), Nicaragua.

Tree or shrub 1-7(-12) $\mathrm{m}$ tall, 8-15 cm diam; young twigs and petiole sparsely covered with appressed hairs, soon glabrous. Leaves: petiole 2-5 $\mathrm{mm}$ long, c. $1 \mathrm{~mm}$ diam; lamina narrowly elliptic to elliptic, $5-16$ by $2-5 \mathrm{~cm}$, membranous, shiny and glabrous above, glabrous below, base acute and slightly attenuate, apex acute to shortly acuminate (acumen to c. $5 \mathrm{~mm}$ long), the extreme tip obtuse to mostly rounded, primary vein slightly impressed to flat above, secondary veins 9-14 on either side of primary vein, flat to slightly raised above, tertiary veins slightly raised to flat above, reticulate. Inflorescence and flower indument: pedicels and outer side of bracts glabrous or sparsely covered with appressed pale brown hairs, outer side of sepals and petals rather densely to sparsely covered with appressed hairs. Inflorescences 1 (or 2)-flowered, leaf-opposed; pedicels 


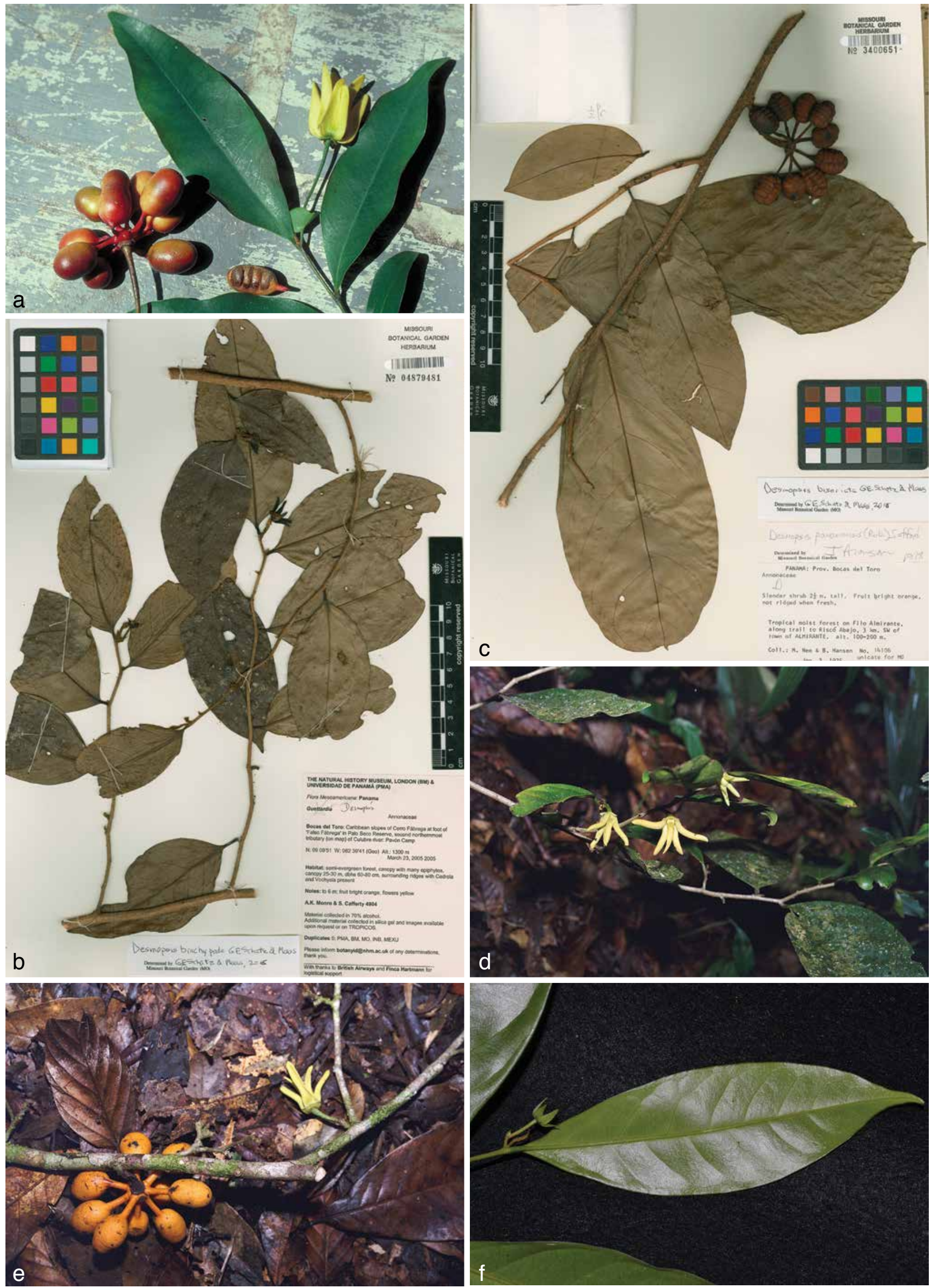

Fig. 1 a. Desmopsis bibracteata (B.L.Rob.) Saff. Flowering and fruiting branches. - b, d, e. Desmopsis brachypoda G.E.Schatz \& Maas. b, d. Flowering branch; e. flowering and fruiting branches. - c. Desmopsis biseriata G.E.Schatz \& Maas. Fruiting branch. — f. Desmopsis colombiana G.E.Schatz \& Maas. Flowering branch (a: Schatz 1087; b. Monro \& Cafferty 4904, type, MO; c. Nee \& Hansen 14106, type, MO; d, e. Monro \& Cafferty 4904; f. Maas et al. 10483). - Photos by: a. G.E. Schatz; d, e. A. Monro; f. P.J.M. Maas. 


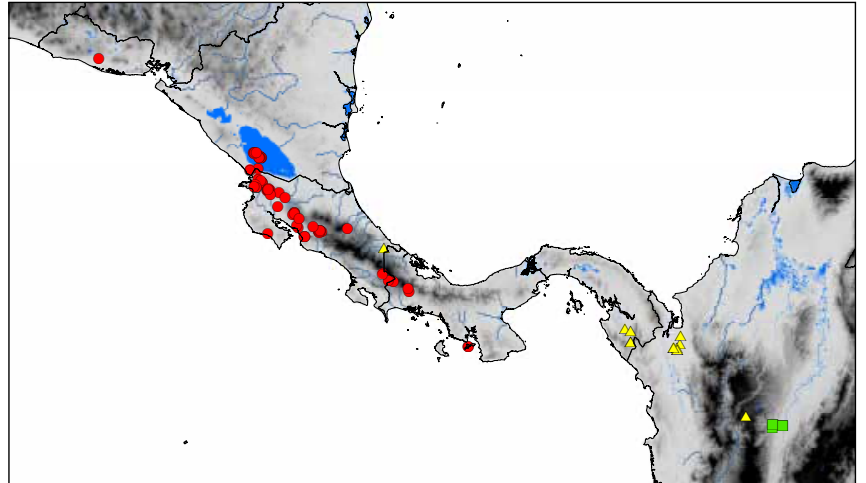

Map 1 Distribution of Desmopsis bibracteata (B.L.Rob.) Saff. (O), D. colombiana G.E.Schatz \& Maas $(\boldsymbol{\square})$ and D. dukei G.E. Schatz (A).

20-50 mm long, 0.5-1 mm diam, to c. $2 \mathrm{~mm}$ diam in fruit; basal bract leafy, broadly ovate to circular, $4-20$ by $4-20 \mathrm{~mm}$, upper bract leafy, broadly ovate-triangular, $3-4$ by $3-4 \mathrm{~mm}$; sepals broadly ovate-triangular, $2-4$ by $2-5 \mathrm{~mm}$, spreading to slightly reflexed; petals green, maturing yellow, brown in sicco, fleshy, subequal, ovate to ovate-triangular, $11-25$ by $5-9 \mathrm{~mm}$, acute, but the extreme tip rounded, margins often revolute. Monocarps $10-30$, green, maturing from yellow, orange, to finally blackpurple, pulp orange, spherical to oblongoid-ellipsoid, 5-20 by $5-10 \mathrm{~mm}$, glabrous or with some appressed hairs when young, apex rounded, usually strongly constricted between the seeds upon drying, wall c. $0.2 \mathrm{~mm}$ thick, stipes $6-17 \mathrm{~mm}$ long, 0.5-1 mm diam. Seeds 1-4, in one row, spherical, discoid or hemispherical, $5-13$ by $2-6 \mathrm{~mm}$, grooved, pitted.

Distribution - El Salvador, Nicaragua, Costa Rica, Panama.

Habitat \& Ecology - In lowland, montane, or semi-deciduous forests. At elevations of $0-1400(-1800) \mathrm{m}$. Flowering: September to April, June; fruiting: all year through.

Vernacular names - Costa Rica: Flor de Guineo (Walker 374), Guinea, Posa de los Indios. El Salvador: Flor de Guineo.

Field observations - 'Flores con aroma dulce' (Acosta 658, Costa Rica); 'flowers smelling like rotting fruit' (Davidse et al. 23479, Costa Rica); 'flores con olor un poco fuerte a frutos de carambola' (Fernández 1729, Costa Rica); 'flores con leve olor a banana' (Jiménez Madrigal 955, Costa Rica); 'flowers very fragrant like banana (methyl-ester, ethyl-acetate), Nitidulid beetles collected from inside flowers' (Schatz \& Janzen 1087 , Costa Rica); 'flores aromáticas' (Solano 946, Costa Rica); 'flowers with an odor like bananas' (Walker 374, Costa Rica).

Note - Typical $D$. bibracteata is distinguished, by its acute apex (with the extreme tip obtuse to rounded), relatively small leaves, small petals with the extreme tip rounded and brown in sicco, having margins that are revolute, and mostly strongly constricted and thin-walled monocarps. Moreover, both bracts are leafy and often persistent.

\section{Desmopsis biseriata G.E.Schatz \& Maas, sp. nov. — Fig. 1c; Map 2}

Desmopsis biseriata is recognized by its large leaves $17-42$ by $9-17 \mathrm{~cm}$, fruiting pedicels $20-25 \mathrm{~mm}$ long, basal and upper scale-like bracts, and by its relatively large monocarps $(12-30$ by $12-20 \mathrm{~mm}$ ) with seeds arranged in two rows, borne on relatively long stipes (10-25 mm long). - Type: Nee \& Hansen 14106 (holo MO), Panama, Bocas del Toro, on Fila Almirante, along trail to Risco Abajo, 3 km SW of town of Almirante, 100-200 m, 3 Jan. 1975.

Tree or shrub $2.5-5 \mathrm{~m}$ tall, c. $5 \mathrm{~cm}$ diam; young twigs and petiole glabrous. Leaves: petiole 5-15 mm long, 1-2 mm diam; lamina elliptic, $17-42$ by $9-17 \mathrm{~cm}$, chartaceous, verruculose on both sides, glabrous above, glabrous below, except for some hairs along primary vein, base obtuse, apex obtuse to

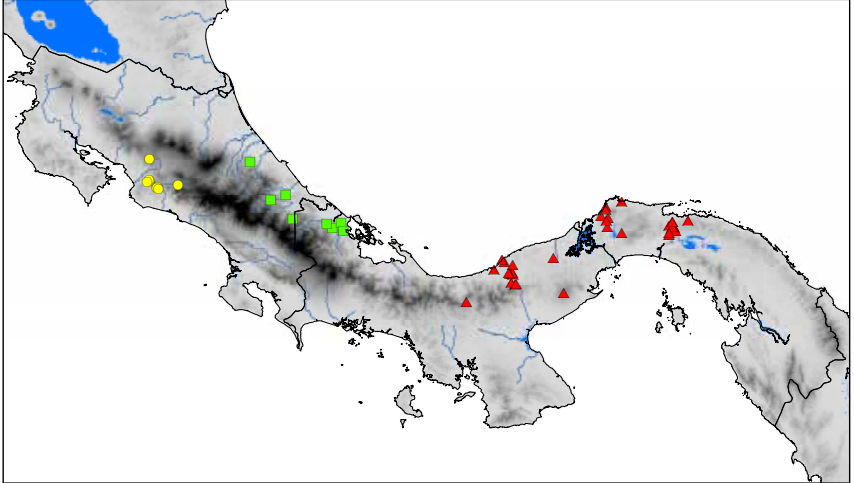

Map 2 Distribution of Desmopsis biseriata G.E.Schatz \& Maas ( $\square)$, D. nigrescens G.E.Schatz (A) and D. oerstedii Saff. (O).

acuminate (acumen 10-15 mm long), primary vein impressed above, secondary veins $5-10$ on either side of primary vein, raised above, tertiary veins slightly raised above, reticulate. Inflorescence and flower indument: pedicels and outer side of bracts sparsely covered with appressed hairs to glabrous. Inflorescences: flowers not seen. Infructescence bearing 1 fruit, leaf-opposed; fruiting pedicels $20-25 \mathrm{~mm}$ long, 2-4 mm diam; basal and upper bract scale-like, broadly ovate-triangular, 1-2 $\mathrm{mm}$ long. Monocarps 5-20, green to yellow, maturing dark purple, ellipsoid-oblongoid to spherical, $12-30$ by $12-20 \mathrm{~mm}$, glabrous, apex rounded, slightly constricted between the seeds upon drying, wall c. $0.5 \mathrm{~mm}$ thick, stipes $10-25 \mathrm{~mm}$ long, 1-2 $\mathrm{mm}$ diam. Seeds $2-14$, in two rows, hemidiscoid or quartispherical, $9-12$ by $6-8$ by $3 \mathrm{~mm}$, grooved and slightly pitted.

Distribution - Costa Rica, Panama.

Habitat \& Ecology - In forest. At elevations of 0-600 m. Flowering: unknown; fruiting: July, October, December.

Vernacular names - Not recorded.

Other specimens examined. CostA RICA, Limón, Talamanca, Bajo Telire, Río Telire, 400-600 m, Gómez P. 24132 (MO); Hitoy Cerere reserve, SW of Valle La Estrella, ridge between Río Cerere and Quebrada Barrera, 150$550 \mathrm{~m}$, Grayum et al. 5814 (MO); Cordillera de Talamanca, along ridge between Quebrada Camagre and Río Barbilla,180-480 m, Grayum et al. 8906 (MO); Reserva Indígena Talamanca Sukut, desembocadura del Río Sukut en el Río Urén, 350-550 m, Hammel et al. 17556 (MO). - PanAmA, Bocas del Toro, c. $15 \mathrm{~km} \mathrm{~S}$ of the town of Changuinola, vicinity of Changuinola 1 dam site, $900-1500 \mathrm{ft}$, Antonio 3140 (MO); on hill above RR station at Milla, 7.5, Croat \& Porter 16414 (MO); Distr. Changuinola, a $1.5 \mathrm{~km}$ de la casa del Sr. Justo Perez, cerca Rancho Quemado, a orillas de la Quebrada Bonyic, 200 m, Hernández et al. 663 (PMA).

Note - Desmopsis biseriata can be recognized by its relatively large monocarps (12-30 by $12-20 \mathrm{~mm}$ ) with seeds arranged in two rows, borne on relatively long stipes $(10-25 \mathrm{~mm}$ long), combined with large leaves up to $42 \mathrm{~cm}$ long, and relatively short pedicels $(20-25 \mathrm{~mm}$ long).

3. Desmopsis brachypoda G.E.Schatz \& Maas, sp. nov. Fig. 1b-e; Map 3

Desmopsis brachypoda is recognized by its leaves which are verruculose on both sides and rather densely to sparsely covered with appressed hairs below, relatively small number of secondary veins (6-8 per side), short pedicels (10-15 mm long) with scale-like basal and upper bracts. - Type: Monro \& Cafferty 4904 (holo MO; iso BM 2 sheets, INB, MEXU, PMA), Panama, Bocas del Toro, Caribbean slope of Cerro Fábrega at foot of 'Falso Fábrega' in Palo Seco Reserve, second northernmost tributary of Culubre River, Pavón Camp, 1300 m, 23 Mar. 2005.

Tree 2-8 $\mathrm{m}$ tall, c. $10 \mathrm{~cm}$ diam; young twigs and petiole rather densely covered with appressed, brown hairs, soon glabrous. Leaves: petiole 5-10 mm long, c. $1 \mathrm{~mm}$ diam; lamina elliptic, $10-16$ by $4-7 \mathrm{~cm}$, chartaceous, verruculose on both sides, 


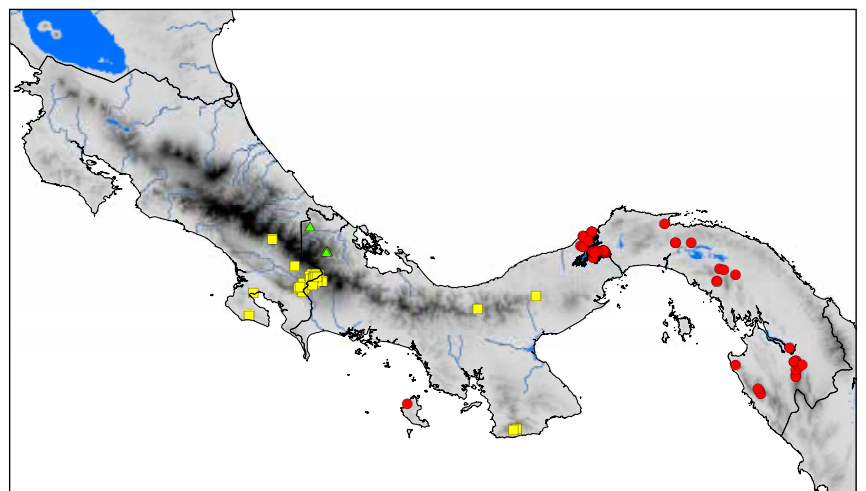

Map 3 Distribution of Desmopsis brachypoda G.E.Schatz \& Maas ( $\mathbf{\Delta})$, D. confusa G.E.Schatz, N.Zamora \& Maas $(\boldsymbol{\square})$ and D. panamensis (B.L.Rob.) Saff. (O).

glabrous above, except for some hairs along primary vein, rather densely to sparsely covered with appressed hairs below, base obtuse and slightly attenuate, apex acute to acuminate (acumen 5-10 $\mathrm{mm}$ long), primary vein impressed above, secondary veins $6-8$ on either side of primary vein, slightly raised above, tertiary veins slightly raised above, reticulate. Inflorescence and flower indument: pedicels and outer side of bracts, sepals, and petals densely to rather densely covered with appressed hairs. Inflorescences 1-2(-8)-flowered, leafopposed; pedicels 10-15 mm long, c. $1 \mathrm{~mm}$ diam; basal and upper bract scale-like, broadly ovate-triangular, $1-3 \mathrm{~mm}$ long; sepals broadly triangular, 4-6 by 4-6 mm, reflexed; petals pale green to pale yellow, subequal, narrowly triangular, 15-21 by 3-4 mm, margins revolute. Monocarps 3-9, yellow-green, maturing bright orange, oblongoid-ellipsoid, 10-22 by 7-15 $\mathrm{mm}$, glabrous, apex rounded, slightly constricted between the seeds upon drying, wall c. $0.3 \mathrm{~mm}$ thick, stipes $4-11 \mathrm{~mm}$ long, 1-3 mm diam. Seeds 2-5, in one row, discoid or hemispherical, $9-11$ by $2-3 \mathrm{~mm}$, smooth to slightly grooved.

Distribution - Panama.

Habitat \& Ecology — In semi-evergreen forest. At elevations of 980-1300 m. Flowering: March; fruiting: March.

Vernacular names - Not recorded.

Other specimens examined. PANAmA, Bocas del Toro, Caribbean slope of Cerro Fábrega at foot of 'Falso Fábrega' in Palo Seco Reserve, second northernmost tributary of Culubre River, Pavón Camp, 980 m, Monro \& Cafferty 4692 (BM, MO, PMA), 1300 m, Monro \& Cafferty 4882 (PMA); Parque Internacional La Amistad, faldas del Cerro Falso Fabrega, 1020 m, Santamaria et al. 7708 (PMA); Changuinola, Parque Internacional La Amistad, $999 \mathrm{~m}$, Solano et al. 5817 (PMA).

Note - Desmopsis brachypoda is distinguished by its relatively short pedicels (10-15 mm long), hence the specific name. It is also characterized by an indument of appressed hairs on the lower leaf side, and a relatively low number of secondary veins (only 6-8).

\section{Desmopsis colombiana G.E.Schatz \& Maas, sp. nov. -} Fig. 1f, 2a; Map 1

Desmopsis colombiana is recognized by its relatively short pedicels (10-30 $\mathrm{mm}$ long) bearing scale-like basal and upper bracts, small, reflexed sepals (1-2 by 1-2 mm), and a small number of monocarps (2-4) with 1-3 seeds. - Type: Cogollo 893 (holo MO), Colombia, Antioquia, San Luis, Parque ecológico, Cañón del Río Claro, sector nor-oriental, margen derecha, 325475 m, 28 Oct. 1983.

Shrub or tree 3-12 m tall, diam not recorded; young twigs and petiole rather densely covered with appressed hairs, soon glabrous. Leaves: petiole 5-10 mm long, c. $2 \mathrm{~mm}$ diam; lamina narrowly elliptic to elliptic, sometimes narrowly ovate-elliptic, $11-20$ by
4-8 cm, chartaceous, shiny and glabrous above, subglabrous below, base acute to obtuse, apex acuminate (acumen 5-20 $\mathrm{mm}$ long), primary vein impressed above, secondary veins $8-10$ on either side of primary vein, raised above, tertiary veins raised above, reticulate. Inflorescence and flower indument: pedicels, outer side of bracts, sepals and petals sparsely to rather densely covered with appressed hairs. Inflorescences 1-3-flowered (sometimes up to 15-flowered), leaf-opposed; flowering and fruiting pedicels $10-30 \mathrm{~mm}$ long, $0.5-1 \mathrm{~mm}$ diam; basal and upper bract scale-like, broadly ovate, $1-2 \mathrm{~mm}$ long; sepals broadly ovate-triangular, $1-2$ by $1-2 \mathrm{~mm}$, reflexed; petals yellow, subequal, narrowly triangular, $15-30$ by $3-5 \mathrm{~mm}$, margins revolute. Monocarps 2-4, maturing red, spherical to ellipsoid, $13-20$ by $12-20 \mathrm{~mm}$, sparsely covered with appressed hairs, soon glabrous, apex rounded, slightly constricted between the seeds upon drying, wall c. $0.5 \mathrm{~mm}$ thick, stipes $5-15 \mathrm{~mm}$ long, c. $1 \mathrm{~mm}$ diam. Seeds $1-3$, in one row, spherical, discoid or hemispherical, $10-11$ by $3-6 \mathrm{~mm}$, grooved.

Distribution - Colombia (Antioquia).

Habitat \& Ecology - In forest. At elevations of 300-600 m. Flowering: June, July, September, October; fruiting: January, March, July, September, October.

Vernacular names - Not recorded.

Other specimens examined. ColomBiA, Antioquia, San Luis, Parque ecológico, Cañón del Río Claro, 350-475 m, Cogollo \& Borja 477 (MO), 325$360 \mathrm{~m}$, Cogollo \& Borja 507 (MO), 330-400 m, Cogollo \& Borja 741 (MO), 340-500 m, Cogollo 1080 (MO), 325 m, Cogollo \& Borja 1220 (MO), 325-500 m, Cogollo 1438 (MO), 350-400 m, Cogollo 1469 (MO); Río Claro, carretera al Cairo, 600 m, Rentería A. \& Cogollo 2745 (MO); Reserva Natural Río Claro, trail up steep slope, 449 m, Maas et al. 10483 (COL).

Notes - Desmopsis colombiana occurs in the Río Claro region in Antioquia. It is characterized by minute, scale-like bracts, relatively short pedicels $(10-30 \mathrm{~mm}$ long), few monocarps (2-4), and small sepals (1-2 mm long).

In some of the collections we found old remnants of pedicels which showed up to 15 flowers or more (Cogollo 1080)!

\section{Desmopsis confusa G.E.Schatz, N.Zamora \& Maas, sp. nov.} - Fig. 2b; Map 3

Desmopsis confusa is recognized by its leaves which are densely covered with long-persisting erect hairs, long pedicels (50-70 mm long, expanding to $120 \mathrm{~mm}$ in fruit) bearing a leafy basal bract and scale-like upper bract, and a relatively large number of monocarps $(10-25)$ with thin walls $(0.1-0.2$ $\mathrm{mm}$ thick) borne on slender stipes (c. $1 \mathrm{~mm}$ diam). - Type: Busey 650 (holo MO; iso DUKE, INIREB, LL, MEXU, NY, PMA, RB, U), Panama, Chiriquí, 2-8 km N of Cañas Gordas, 1000-1100 m, 26 Feb. 1973.

Shrub or tree 2-10 m tall, diam not recorded; young twigs and petiole densely covered with long-persisting, erect, brownish hairs $0.2-0.5 \mathrm{~mm}$ long (velutinous). Leaves: petiole $3-10 \mathrm{~mm}$ long, 1-2 mm diam; lamina elliptic to ovate or narrowly so, $8-19(-22)$ by $3-7(-9) \mathrm{cm}$, chartaceous, glabrous above, but primary vein mostly covered with erect, brown hairs, densely covered with long-persisting, erect, brownish hairs $0.2-0.4$ $\mathrm{mm}$ long below (velutinous), base acute to obtuse, apex acute to acuminate (acumen 5-10 mm long), the extreme tip mostly obtuse, primary vein impressed above, secondary veins $6-10$ on either side of primary vein, slightly raised above, tertiary veins slightly raised above, reticulate to slightly percurrent. Inflorescence and flower indument: pedicels and outer side of bracts, and sepals densely to rather densely covered with erect hairs (velutinous), petals densely to rather densely covered with mainly appressed hairs. Inflorescences 1- or 2-flowered, leaf-opposed, but sometimes produced from the main trunk; pedicels $50-70 \mathrm{~mm}$ long, $0.5-1 \mathrm{~mm}$ diam, to $60-120 \mathrm{~mm}$ long and 1-2 $\mathrm{mm}$ diam in fruit; basal bract leafy, broadly ovate to broadly ovate-cordate, $2-25$ by $3-20 \mathrm{~mm}$, upper bract scale- 


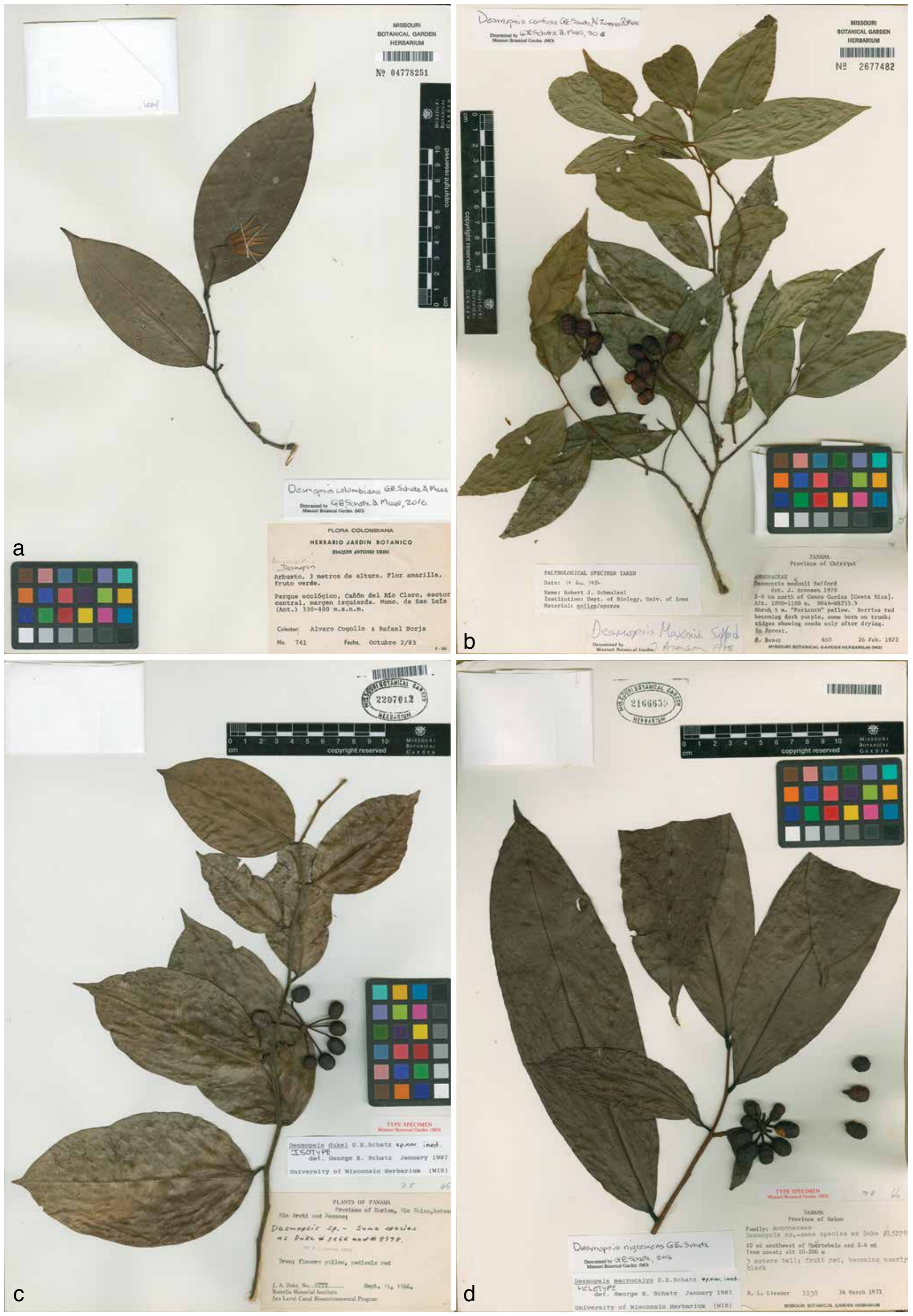

Fig. 2 a. Desmopsis colombiana G.E.Schatz \& Maas. Flowering branch. - b. Desmopsis confusa G.E.Schatz, N. Zamora \& Maas. Fruiting branch. c. Desmopsis dukei G.E.Schatz. Fruiting branch. — d. Desmopsis nigrescens G.E.Schatz. Fruiting branch (a: Cogollo \& Borja 741; b: Busey 650, type; c: Duke 8777 , type; d: Liesner 1038, type; all MO). 
like, mostly $<1 \mathrm{~mm}$ long, hardly observable; sepals ovatetriangular, 4-6(-9) by 3-4 $\mathrm{mm}$; petals green, maturing yellow, equal, narrowly triangular to ovate-triangular, 10-20 by 4-9 mm. Monocarps 10-25, green to yellow, maturing red to finally dark purple to black, oblongoid-ellipsoid to spherical, $5-25$ by $5-15 \mathrm{~mm}$, sparsely covered with appressed hairs, soon glabrous, apex rounded, slightly constricted between the seeds upon drying, wall $0.1-0.2 \mathrm{~mm}$ thick, stipes $5-15 \mathrm{~mm}$ long, c. $1 \mathrm{~mm}$ diam. Seeds $1-5$, in one row, speroid, discoid or hemispherical, $6-10$ by $2-3 \mathrm{~mm}$, pale brown, grooved.

Distribution - Costa Rica, Panama.

Habitat \& Ecology — In premontane wet forest. At elevations of $1000-1800 \mathrm{~m}$, sometimes going down to $100 \mathrm{~m}$. Flowering: January to March, and May; fruiting: all year through.

Vernacular names - Not recorded.

Field observations - 'Flowers smell like ripe bananas' (Burger \& Mata 4446, Schatz 1061, Costa Rica).

Other specimens examined. Costa RICA, Puntarenas, Reserva Forestal Golfo Dulce, entrada a Chocuaco, Rincón, 100 m, Aguilar 629 (MO); Cuenca Terraba-Sierpe, Las Melliza, Cafrosa, 1200 m, Alfaro 1936 (MO); Cerro Pando, ridges above the Río Coton and the Río Negro, 1000-1800 m, Barringer \& Gómez 1635 (CR, F, MO); Forested slopes E of Las Cruces and $5-6 \mathrm{~km}$ S of San Vito on and around the property of Mr. Robert Wilson, 1100-1200 m, Burger \& Matta 4446 (F), 4468 (F), 4492 (F, GH, LL, US); forest remnant on slopes NE of Sabalito along road to La Union, $800 \mathrm{~m}$, Burger \& Matta 4539 (BM, F, MO, NY); Cantón de Buenos Aires, Ujarrás, cabeceras del Río Kuiyé, siguiendo la fila que lleva a Olán, 1400 m, Chacón 369 (CR, F, MO); Finca Loma Linda, 1 mile SW of Cañas Gordas, 1150 m, Croat 22234 (MO, NY); vicinity of first large concrete culvert before Finca Las Alturas at Cotón, Río Cotón, 1300 m, Croat 44378 (MO, U); 6 km S of San Vito de Java at Finca las Cruces, Gillis \& Plowman 10149 (F, U); Cotón, base SW Cerro Pando, 1300 m, Gómez et al. 18132 (CR); La Tigra - Las Mellizas, 1280 m, Gómez et al. 21968 (F, MO, U); Coto Brus, San Vito, Las Cruces, Jardín Botánico R. \& S. Wilson, sendero principal alrededor de la Estación, 1200 m, Gómez-Laurito et al. 11925 (CR, F, MO); Cuenca Térraba-Sierpe, Altamira, Finca de ASOPROLA, 1100 m, González et al. 431 (INB, MO); along Río Marzo, near crossing of road c. $3 \mathrm{~km}$ SW of Las Alturas de Coto Brus, 1310 m, Grayum \& Hammel 5658 (MO); Jardín Botánico Wilson, primary forest on slopes and ridges to W of Río Jaba, 1.5-2 km SW of Las Cruces de Coto Brus, 1140 m, Grayum 9272 (MO); above La Tigra, Talamanca Mts, 1400-1600 m, Hazlett 5068 (F); Cantón de Golfito Jiménez, Dos Brazos de Río Tigre, cuenca superior del Río Madrigal, 300 m, Herrera 4694 (CR, MO); Cuenca Terraba-Sierpe, hacienda la Amistad, Zona Protectora Las Tablas, 1256 m, Kriebel 3 (INB); Las Alturas de Cotón N of San Vito de Java, $4000 \mathrm{ft}$, Las Cruces Tropical Botanical Garden 74-225 (MO); Zona Protectora Las Tablas Sector Río Negro abajo, 1600-1800 m, Mora 239 (CR, INB, MO); N of La Lucha on road to Progresso, 1200 m, Murphy 1228 (DUKE), Murphy 1246 (DUKE); Coto Brus, Finca Cafrosa, 1220 m, Navarro 265 (INB, MO); around Wilson's finca, $6 \mathrm{~km} \mathrm{~S}$ of San Vito de Java, $4000 \mathrm{ft}$, Raven 20924 (F); along Río Jaba, S of San Vito de Coto Brus, 1150 m, Schatz 1001 (MO); Las Cruces Botanical Garden, about $5 \mathrm{~km}$ S of San Vito along road to Villa Neily, 1100-1200 m, Schatz 1061 (MO, WIS); alrededores de La Amistad Lodge, 1400-1600 m, Solano \& Kriebel 807 (INB); S of San Vito de Java, in the area immediately around Las Cruces Gardens, 1200-1300 m, Taylor 3536 (DUKE); N of San Vito near Panamanian border between La

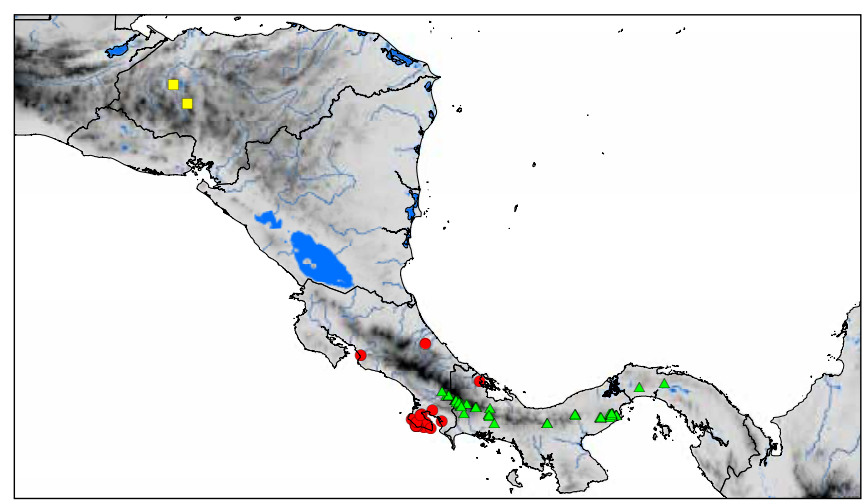

Map 4 Distribution of Desmopsis dolichopetala R.E.Fr. (口), D. maxonii Saff. $(\mathbf{\Delta})$ and D. verrucipes Chatrou, G.E.Schatz \& N.Zamora (O).
Lucha and Progresso at third river crossing, $1250 \mathrm{~m}$, Taylor 3584 (DUKE). - Panama, Chiriquí, along road between Volcán and Río Sereno, 13.7 miles W of Volcán, 1200 m, Croat 66322 (MO, U); 19 km W of Río Chiriquí Viejo on road to San Sereno, 1200 m, D'Arcy 10833 (MO, U); Finca Ojo de Aqua, 1300 m, Knapp 1583 (MO, U). Veraguas, Cerro Hoya, subiendo por Cobachón, 750 m, Deago et al. 196 (MO, PMA, U), 199 (PMA); El Pantano, Parque Nacional Santa Fé, Alto Los Gonzales, 918 m, Espinosa et al. 6127 (MO, PMA); forest along Río Gatu above Chitra Bajo, NW of Laguna La Yeguada, 650 m, McPherson 8013 (MO, PMA, U); Parque Nacional Cerro Hoya, 900 m, Rivera 321 (PMA).

Note - Desmopsis confusa has often been misidentified as $D$. oerstedii, a species occurring only in Costa Rica. Because of that confusion we have named it $D$. confusa. Both species are densely covered with erect hairs on most vegetative parts. It differs from $D$. oerstedii by its thin-walled monocarps $(0.1-0.2$ $\mathrm{mm}$ vs $2-4 \mathrm{~mm}$ ), and thinner stipes (c. $1 \mathrm{~mm}$ vs $2-4 \mathrm{~mm}$ thick).

\section{Desmopsis dolichopetala R.E.Fr. - Map 4}

Desmopsis dolichopetala R.E.Fr. (1941) 106. - Type: Yuncker et al. 6155 (holo S; iso F, MO, NY, U), Honduras, near the summit of the ridge above El Achote, in cloud zone, above the plains of Siguatepeque, $1800 \mathrm{~m}, 28$ July 1936

Tree 6-8 $\mathrm{m}$ tall, 10-12 cm diam; young twigs and petiole rather densely covered with appressed hairs, soon glabrous. Leaves: petiole 2-7 $\mathrm{mm}$ long, c. $1 \mathrm{~mm}$ diam; lamina narrowly elliptic, 8-22 by $3-7 \mathrm{~cm}$, membranous, glabrous above, sparsely covered with appressed hairs, mainly along primary vein below to subglabrous below, base acute to obtuse and slightly attenuate, apex acute to acuminate (acumen $5-10 \mathrm{~mm}$ long), primary vein impressed above, secondary veins 9-12 on either side of primary vein, slightly raised above, tertiary veins slightly raised above, reticulate. Inflorescence and flower indument: pedicels sparsely covered with appressed hairs, outer side of bracts densely so, outer side of sepals and petals densely to sparsely so. Inflorescences 1- or 2-flowered, leaf-opposed or produced from the main trunk; pedicels $60-90 \mathrm{~mm}$ long, c. $1 \mathrm{~mm}$ diam, slightly increasing in diameter from base to apex, to c. $3 \mathrm{~mm}$ diam in fruit; basal and upper bracts scalelike, broadly ovate-triangular, 1-2 mm long, soon falling; sepals shallowly ovate-triangular, $1-2$ by $2-3 \mathrm{~mm}$; petals yellow to yellow-bluff, tinged with pink, subequal, narrowly triangular, $30-55$ by $3-6 \mathrm{~mm}$. Monocarps $3-12$, red, orange inside in vivo, spherical to oblongoid-ellipsoid, $15-45$ by $15-25 \mathrm{~mm}$, sparsely covered with appressed hairs, soon glabrous, apex rounded, not constricted between the seeds upon drying, wall c. $1 \mathrm{~mm}$ thick, stipes 3-6 mm long, 2-3 mm diam. Seeds 2-4, in one row, discoid or hemispherical, $20-21$ by $6-10 \mathrm{~mm}$, smooth to slightly grooved.

Distribution - Honduras.

Habitat \& Ecology - In forests in cloud zone. At elevations of 1400-1800 m. Flowering: May, July; fruiting: May, July.

Vernacular names - Not recorded.

Field observations - 'Flowers green, then yellow with a banana odor' (Walker 431, Honduras).

Note - Desmopsis dolichopetala, so far only known from two collections from Honduras, is very close to $D$. schippii, differing in: more numerous secondary veins (9-12 vs $6-8)$, larger monocarps (15-45 vs $10-27 \mathrm{~mm}$ ), and larger seeds (20-21 by $6-10$ vs $8-15$ by $3-5 \mathrm{~mm}$ ). Moreover, $D$. dolichopetala occurs at higher altitudes (1400-1800 m), whereas D. schippii normally grows at much lower elevations.

\section{Desmopsis dukei G.E.Schatz, sp. nov. - Fig. 2c; Map 1}

Desmopsis dukei is recognized by its leaves and pedicels which are densely covered with long-persisting erect hairs, relatively short flowering pedicels (10-16 mm long), with a leafy often soon falling basal bract, and a scale- 
like or leafy upper bract, and 10-20 monocarps borne on relatively long and slender stipes (12-25 mm long, 0.5-1 mm diam). - Type: Duke 8777 (holo MO; iso MO, US), Panama, Darién, Río Balsa, between Río Areti and Manane, 14 Sept. 1966.

Tree or shrub 4-20 m tall, 5-7.5 cm diam; young twigs and petiole densely covered with long-persisting, pale brown, erect hairs to c. $0.5 \mathrm{~mm}$ long. Leaves: petiole $2-6 \mathrm{~mm}$ long, c. $1 \mathrm{~mm}$ diam; lamina elliptic, $8-18$ by $4-9 \mathrm{~cm}$, chartaceous, shiny and glabrous above, but often with a row of erect hairs along the primary vein, densely covered with long-persisting, pale brown, erect hairs to c. $0.3 \mathrm{~mm}$ long (velutinous) below, base acute to obtuse, apex acuminate (acumen 5-10 mm long), primary vein impressed above, secondary veins $7-9$ on either side of primary vein, slightly raised above, tertiary veins flat to slightly raised above, reticulate. Inflorescence and flower indument: pedicels and sepals densely covered with long-persisting, pale brown, erect hairs to c. $0.5 \mathrm{~mm}$ long, outer side of bracts and petals densely to rather densely covered with appressed hairs. Inflorescences 1- or 2-flowered, leaf-opposed; pedicels 10-16 mm long, c. $1 \mathrm{~mm}$ diam, to c. $25 \mathrm{~mm}$ long and c. $2 \mathrm{~mm}$ diam in fruit; basal bract usually leafy, ovate, $2-12$ by $1.5-8 \mathrm{~mm}$, often soon falling, upper bract scale-like to comparable in size and shape to basal bract; sepals broadly triangular, $5-8$ by $3-7 \mathrm{~mm}$; petals yellow, subequal, narrowly triangular, $10-30$ by $4-7$ $\mathrm{mm}$. Monocarps 10-20, yellow, orange, red, maturing purpleblack, spherical to oblongoid, $9-18$ by $7-14 \mathrm{~mm}$, sparsely covered with appressed hairs, soon glabrous, apex rounded, sometimes slightly constricted between the seeds upon drying, wall c. $0.5 \mathrm{~mm}$ thick, stipes $12-25 \mathrm{~mm}$ long, $0.5-1 \mathrm{~mm}$ diam. Seeds 1-5, in one row, spherical, discoid or hemispherical, 7-9 by $4-6 \mathrm{~mm}$, pitted.

Distribution - Costa Rica, Panama, Colombia (Antioquia, Chocó).

Habitat \& Ecology - Tropical wet forest. At elevations of 0-500 m. Flowering: March, June, July, September; fruiting: February to April, June to September, November, December.

Vernacular names - Not recorded.

Other specimens examined. ColomBIA, Antioquia, Turbo, Corregimiento Lomas Aisladas, Finca Las Aisladas, 30 m, Alzate \& Cardona 1070 (U), 1258 (MO); $11 \mathrm{~km}$ despues de Barranquillita, $80 \mathrm{~m}$, Brand \& Cogollo 48 (JAUM, MO); 12 km despues de Barranquillita, 80 m, Brand \& Cogollo 61 (JAUM, $\mathrm{MO}$ ); 14 kms despues de Barranquillita, $80 \mathrm{~m}$, Brand \& Cogollo 138 (JAUM, MO); Carretera Tapón del Darién, sector Río León-lomas aisladas, km 37, $20 \mathrm{~m}$, Brand \& Lozano 912 (MO), 1063 (MO). Chocó, Riosuccio, orillas del Río Truando, en Teresita, Arcizia 159 (COL); Región de Urabá, Cerro del Cuchillo, Sector Noreste, 50-200 m, Cárdenas 815 (MO), Región de Urabá, Cerro del Cuchillo, Sector Noreste, 400-500 m, Cárdenas 855 (MO), 859 (MO), 863 (MO); Camino de Cidón a la Cumbre Sureste, 50-100 m, Cárdenas 2083 (HUA, JAUM, MO, U); Zona de Urabá, Cerros del Cuchillo, Sector Cuchillo Blanco (Piedemonte), 50-100 m, Cárdenas 2272 (MO); near Madurex Logging Camp above Teresita and below the rapids on R. Truando, Duke 9917 (MO, US); Parque Natural Nacional Los Katyos, Tilupo, camino quebrada del Medio, 250-330 m, León 487 (MO). - Costa RıcA, Limón, bosques cercanos al sitio de exploración petrolera, Suretka, $200 \mathrm{~m}$, GomezLaurito 8808 (F). - PANAMA, Darién, parallel to Río Tucutí on ridge upstream c. 2 hrs (piragua) above Tucutí, 160 m, Duke 5266 (MO); Río Balsa, between Río Areti and Manene, 105-130 m, Duke 8798 (MO).

Note - Desmopsis dukei can be recognized by the longpersisting indument of erect hairs on the pedicels and lower side of leaves and relatively short pedicels (10-25 $\mathrm{mm}$ long).

\section{Desmopsis erythrocarpa Lundell - Map 5}

Desmopsis erythrocarpa Lundell (1974) 26. — Type: Contreras 5976 (holo LL; iso DUKE, ENCB, F), Guatemala, Petén, Cadenas, bordering Río Sarstun, in high forest of wet land, W of km 170 of Poptun Road, 14 Aug. 1966.

Tree or shrub 3-6 m tall, $2.5-5 \mathrm{~cm}$ diam; young twigs and petiole sparsely covered with appressed hairs. Leaves: petiole 2-8 $\mathrm{mm}$ long, 1-2 mm diam; lamina narrowly elliptic to elliptic,

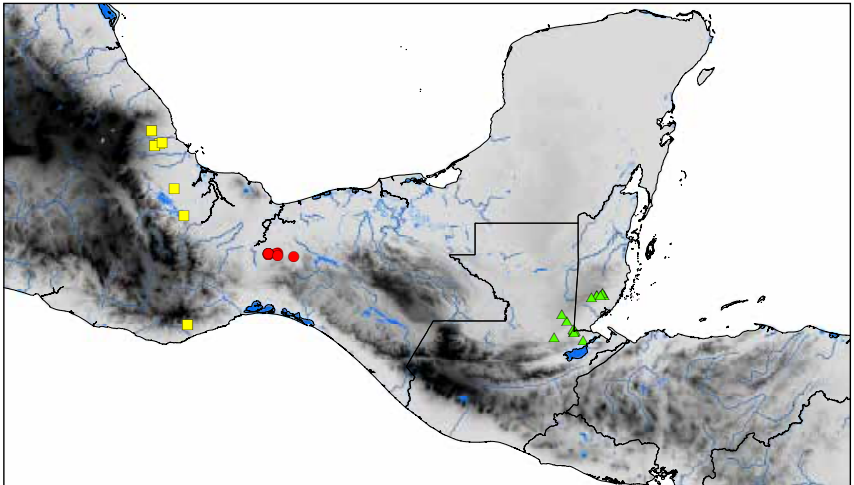

Map 5 Distribution of Desmopsis erythrocarpa Lundell $(\mathbf{\Delta})$, D. trunciflora (Schltdl. \& Cham.) G.E.Schatz (ם) and D. uxpanapensis G.E.Schatz (O)

$8-22$ by $3-8 \mathrm{~cm}$, chartaceous, glabrous above, glabrous, but primary vein often densely covered with appressed hairs below, base acute to attenuate, apex long-acuminate (acumen 5-25 $\mathrm{mm}$ long), the extreme tip obtuse, primary vein impressed above, secondary veins 8-12 on either side of primary vein, slightly raised above, tertiary veins flat above, reticulate. Inflorescence and flower indument: pedicels and outer side of bracts, sepals, and petals sparsely to densely covered with appressed hairs. Inflorescences 1- or 2-flowered, leaf-opposed; flowering and fruiting pedicels $20-80 \mathrm{~mm}$ long, $0.5-1 \mathrm{~mm}$ diam; basal and upper bracts scale-like, broadly ovate-triangular, 1-3 $\mathrm{mm}$ long; sepals ovate-triangular, $3-12$ by $3-4 \mathrm{~mm}$, spreading to reflexed; petals green to yellow, subequal, linear to narrowly ovate-triangular $20-45$ by $2-4 \mathrm{~mm}$, margins revolute. Monocarps 5-15, pale green, yellow, maturing dark red, spherical to ellipsoid, $8-15$ by $6-12 \mathrm{~mm}$, sparsely covered with appressed hairs, soon glabrous, apex rounded, wall c. $0.5 \mathrm{~mm}$ thick, stipes 5-15 mm long, c. $1 \mathrm{~mm}$ diam, strongly verruculose. Seeds 1 or 2 , in one row, subspherical or hemispherical, 8-10 by $5-8 \mathrm{~mm}$, grooved.

Distribution - Belize and Guatemala.

Habitat \& Ecology - Semi-evergreen forest, on limestone soil. At elevations of 45-420 m. Flowering: May, June, August; fruiting: March, May.

Vernacular names - Guatemala: Anona (Contreras 5976), Anonilla, Cabo de Hacha.

Note - Desmopsis erythrocarpa is recognized by longacuminate leaves, non-foliaceous scale-like bracts, and small (8-15 by $6-12 \mathrm{~mm}$ ), 1- or 2-seeded monocarps.

\section{Desmopsis guerrerensis Gonz.-Martínez \& J.Jiménez} Ram. - Map 6

Desmopsis guerrerensis Gonz.-Martínez \& J.Jiménez Ram. in JiménezRamírez \& González-Martínez (2016) 51. — Type: C.A. González-Martínez \& S. Rios-Carrasco 892 (holo FCME; iso FCME, NY), Mexico, Guerrero, Mun. Chilpancingo de los Bravo, Acahuizotla, en ladera cerca de rio, 20 Feb. 2015.

Tree 3-4 m tall, diam not recorded; young twigs covered with appressed, yellow hairs or glabrescent. Leaves: petiole 3-7 mm long, $1 \mathrm{~mm}$ diam, sparsely to moderately covered with appressed hairs or glabrescent; lamina elliptic, (3.6-)4.5-13.5 by $(1.6-) 2-4.5 \mathrm{~cm}$, chartaceous to membranous, glabrous above, sparsely covered with appressed hairs or glabrescent below and with evident oil bodies (glands), non-verrucose, base cuneate to obtuse, apex acuminate (acumen to $20 \mathrm{~mm}$ long), the extreme tip slightly rounded, primary vein impressed above, glabrous, raised below, sparsely covered with appressed hairs, secondary veins 8-11 on either side of primary vein, flat above, slightly raised below, tertiary veins flat above, slightly raised 


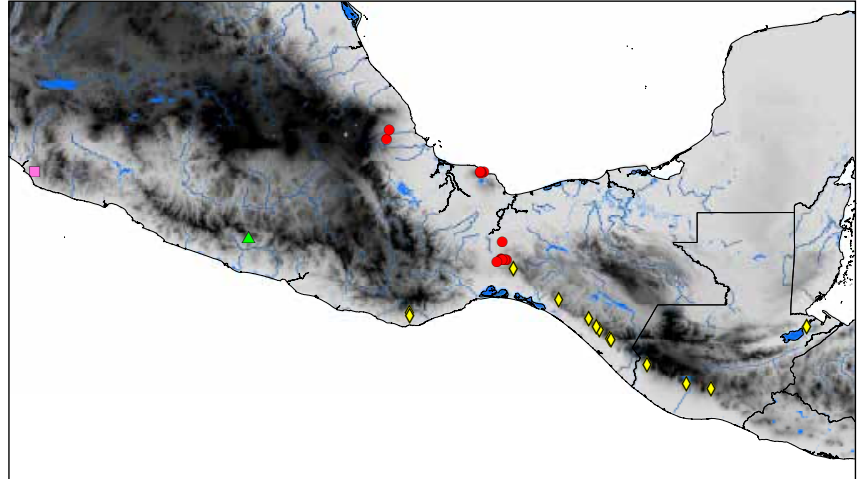

Map 6 Distribution of Desmopsis lanceolata Lundell $(\downarrow), D$. guerrerensis

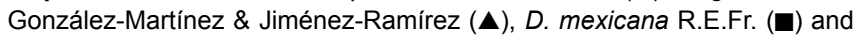
D. subnuda (R.E.Fr.) G.E.Schatz \& Maas (@).

below, reticulate. Inflorescence and flower indument: pedicels and outer side of bracts, outer side of sepals, and outer side of petals sparsely to densely covered with appressed yellowish to white hairs. Inflorescences 1-flowered, sub-leaf-opposed or terminal; pedicels $26-43 \mathrm{~mm}$ long, elongating to $44-51 \mathrm{~mm}$ in fruit, $0.5-1.3 \mathrm{~mm}$ diam; basal bracts 1 or 2, leafy, ovate, $14-17(-20)$ by $9-13 \mathrm{~mm}$, base cordate to obtuse, apex acute, sometimes soon falling off, upper bract scale-like, 1.25-2 mm long, lanceolate; sepals ovate, $3-4$ by $3-3.2 \mathrm{~mm}$ at anthesis, accrescent and persistent in fruit, (5-)7-9 by $5-6.5(-7) \mathrm{mm}$; petals green, subequal, ovate to narrowly ovate, $5.5-10.7$ by $2.7-3.3 \mathrm{~mm}$, the margin sometimes revolute, the apex incurved. Monocarps $5-10$, red at maturity, subspherical to ovoid, $8-17 \mathrm{~mm}$ long, 8-15 mm diam, sparsely covered with appressed white hairs near the base, base and apex rounded, not constricted between the seeds upon drying, wall $0.4-0.5 \mathrm{~mm}$ thick, stipes $6-8 \mathrm{~mm}$ long, c. $1.5 \mathrm{~mm}$ diam. Seeds 2 or 3 , in one row, discoid or hemispherical, $9-10.5$ by $2-5.5 \mathrm{~mm}$, finely grooved.

Distribution - Mexico.

Habitat \& Ecology - Semi-deciduous forest. At elevations of c. $800 \mathrm{~m}$. Flowering: February; fruiting: March.

Vernacular names - Not recorded.

Note - Desmopsis guerrerensis is recognized by its leaves with evident glandular oil bodies on the upper and lower surface, a leafy lower bract on the pedicel, persistent and accrescent sepals in fruit, and subspherical to ovoid monocarps with 2 or 3 seeds.

\section{Desmopsis heteropetala R.E.Fr. - Map 7}

Desmopsis heteropetala R.E.Fr. (1931) 316. - Type: Pittier 7967 (holo BR), Costa Rica, San José, 'Forêts de Tablazo', Mar. 1893.

Shrub or tree 2-7 m tall, 5-10 cm diam; young twigs and petiole glabrous. Leaves: petiole 3-8 $\mathrm{mm}$ long (but often appearing subsessile because of the cordate base of the lamina), 2-4 mm diam; lamina elliptic to narrowly elliptic, $15-40$ by $6-17 \mathrm{~cm}$, coriaceous, shiny on both sides, glabrous above and below, base cordate, apex acute to acuminate (acumen 10-25 mm long), primary vein slightly impressed above, raised and strongly keeled below, secondary veins $10-15$ on either side of primary vein, slightly raised above, tertiary veins raised above, reticulate. Inflorescence and flower indument: pedicels and outer side of bracts glabrous, outer side of sepals and petals sparsely to rather densely covered with appressed hairs. Inflorescences 1 or 2-flowered, leaf-opposed; pedicels $45-80 \mathrm{~mm}$ long, $1-3 \mathrm{~mm}$ diam, 80-140 $\mathrm{mm}$ long and 2-5 mm diam in fruit; basal bract leafy, broadly ovate to circular, $15-40$ by $15-40 \mathrm{~mm}$, upper bract scale-like, 1-2 mm long; sepals shallowly ovate-triangu-

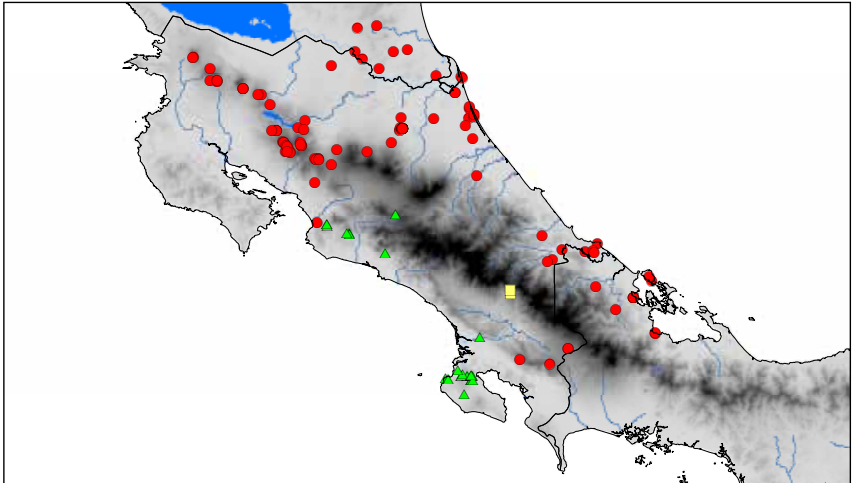

Map 7 Distribution of Desmopsis heteropetala R.E.Fr. (A), D. microcarpa R.E.Fr. (O) and D. talamancana G.E.Schatz \& Maas ( $\square$ )

lar, $3-5$ by $3-4 \mathrm{~mm}$, spreading; petals cream, unequal, outer petals narrowly ovate-triangular to ovate-triangular, $8-20$ by $5-12 \mathrm{~mm}$, inner ones narrowly ovate-triangular, $8-20$ by $3-5$ $\mathrm{mm}$. Monocarps $5-10$, yellow or orange, finally shiny red to purple-black, spherical to ellipsoid, $20-38$ by $16-27 \mathrm{~mm}$, glabrous, apex rounded, not constricted between the seeds upon drying, wall $2-4 \mathrm{~mm}$ thick, stipes $2-10$ by $2-6 \mathrm{~mm}$. Seeds $2-8$, in two rows, hemidiscoid or quartispherical, $6-15$ by $2-4$ $\mathrm{mm}$, grooved.

Distribution - Costa Rica.

Habitat \& Ecology - In primary or secondary lowland rain forest. At elevations of 0-500 m. Flowering: February to April, September, October; fruiting: May, September to November.

Vernacular names - Not recorded.

Note - Desmopsis heteropetala is easily recognizable by its large leaves with a cordate base, and primary vein strongly keeled on the lower side. The monocarps are large (20-38 $\mathrm{mm}$ long), spherical to ellipsoid, and without any constriction between the two rows of seeds. Moreover, the monocarps are very thick-walled (wall to $4 \mathrm{~mm}$ thick).

\section{Desmopsis lanceolata Lundell - Map 6}

Desmopsis lanceolata Lundell (1939) 85, t. 3. - Type: Matuda 2299 (holo $\mathrm{MICH}$; iso A, CAS, F, K, LL, MEXU 2 sheets, MO, NY, US 2 sheets, WIS), Mexico, Chiapas, Mt Ovando, Dec. 1937.

Desmopsis guatemalensis Standl. \& Steyerm. (1944) 156. - Type: Steyermark 34304 (holo F), Guatemala, Quezaltenango, Montaña Chicharro, lower southeastern slopes of Volcán de Santa María, 1500 m, 17 Jan. 1940 Desmopsis izabalensis Standl. \& Steyerm. (1944) 157. — Type: Steyermark 41543 (holo F; iso US), Guatemala, Izabal, on ridge top, along Río Frío, Cerro San Gil, 75-150 m, 18 Dec. 1941.

Shrub or tree 2.5-6 m tall, diam not recorded; young twigs and petiole densely covered with erect and appressed, golden brownish hairs. Leaves: petiole 2-8 $\mathrm{mm}$ long, c. $1 \mathrm{~mm}$ diam; lamina narrowly elliptic, $4-10$ by $1-3.5 \mathrm{~cm}$, chartaceous, shiny, sometimes the primary vein covered with some erect hairs to glabrous above, sparsely covered with appressed and erect hairs below, but primary vein densely so to glabrous, base acute, apex acute to obtuse, sometimes shortly acuminate (acumen to c. $5 \mathrm{~mm}$ long), the extreme tip rounded, primary vein impressed above, secondary veins $6-10$ on either side of primary vein, raised to flat above, tertiary veins flat to slightly raised above, reticulate. Inflorescence and flower indument: pedicels and outer side of bracts and sepals densely to rather densely covered with erect and appressed hairs, outer side of petals rather densely covered with appressed hairs. Inflorescences 1- or 2-flowered, leaf-opposed; pedicels $15-20$ by c. $1 \mathrm{~mm}$ diam, to c. $25 \mathrm{~mm}$ long and c. $1 \mathrm{~mm}$ diam in fruit; basal bract leafy, broadly ovate 

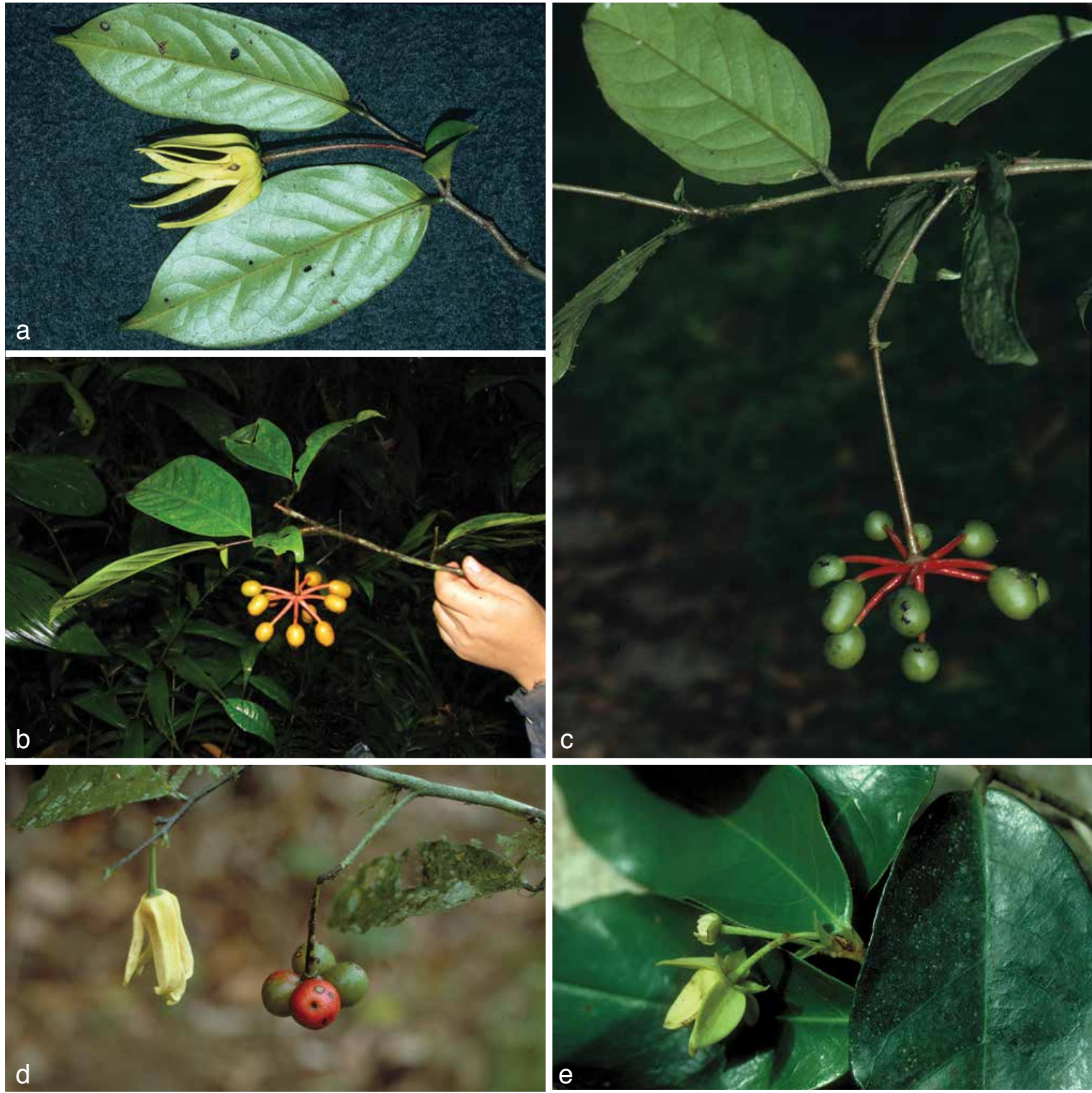

Fig. 3 a, c. Desmopsis maxonii Saff. a. Flowering branch; c. fruiting branch. — b. Desmopsis nigrescens G.E.Schatz. Fruiting branch. - d. Desmopsis schippii Standl. Flowering and fruiting branch. - e. Desmopsis subnuda (R.E.Fr.) G.E.Schatz \& Maas. Flowering branch (a: Maas et al. 9550; b: McPherson 20042; c: Maas et al. 9547; d: Schatz 1030; e: Schatz \& Alverson 1191). — Photos by: a, c. P.J.M. Maas; b. J. Meerman; d, e. G.E. Schatz.

to circular, $12-20$ by $8-15 \mathrm{~mm}$, upper bract scale-like, broadly ovate-triangular, 1-2 mm long; sepals broadly ovate-triangular, $2-10$ by $2-4 \mathrm{~mm}$, reflexed; petals yellow, outer ones pale orange at the inner base, subequal, narrowly triangular, 10-20 by $2-4 \mathrm{~mm}$. Monocarps $2-10(-15)$, orange to dull red, spherical to oblongoid-ellipsoid, $4-12$ by $4-12 \mathrm{~mm}$, sparsely covered with appressed hairs, soon glabrous, apex rounded, rarely constricted between the seeds upon drying, wall c. $0.5 \mathrm{~mm}$ thick, stipes 2-8 mm long, c. $1 \mathrm{~mm}$ diam. Seeds 1 or 2 , in one row, subspherical or hemispherical, $6-9$ by $4-7 \mathrm{~mm}$, strongly grooved.

Distribution - Mexico (Chiapas, Oaxaca), Guatemala.

Habitat \& Ecology — In evergreen and semi-evergreen tropical forest. At elevations of 75-2000 m. Flowering: November to January, March; fruiting: January, March, June, September.

Vernacular names - Not recorded.
Note - Desmopsis lanceolata is characterized by its small narrow leaves ( $4-10$ by $1-3.5 \mathrm{~cm}$ ), its small and often spherical, 1 - or 2-seeded monocarps (4-11 by $4-10 \mathrm{~mm}$ ), and a dense indument of erect and appressed hairs on the young twigs.

\section{Desmopsis maxonii Saff. - Fig. 3a, c; Map 4}

Desmopsis maxonii Saff. (1916) 188, pl. 8. - Type: Pittier 3154 (holo US; iso US 2 sheets), Panama, Chiriquí, near El Boquete, 1000-1300 m, 16 Mar. 1911.

Tree or shrub 1.5-10 m tall, 3-12 cm diam; young twigs and petiole glabrous. Leaves: petiole $3-8 \mathrm{~mm}$ long, c. $1 \mathrm{~mm}$ diam; lamina ovate to elliptic or narrowly so, $8-22$ by $3-8 \mathrm{~cm}$, chartaceous, glabrous above, glabrous or rarely sparsely covered with appressed hairs below, base acute to obtuse, rarely attenuate, apex acuminate (acumen 5-15 mm long), primary 
vein impressed above, secondary veins $6-8$ on either side of primary vein, slightly raised above, tertiary veins raised to flat above, reticulate. Inflorescence and flower indument: pedicels and outer side of bracts glabrous or sometimes sparsely covered with appressed hairs, outer side of sepals and petals sparsely to rather densely covered with appressed hairs. Inflorescences 1-4-flowered, leaf-opposed; pedicels 25-110 mm long, $0.5-1 \mathrm{~mm}$ diam, to $1.5-2 \mathrm{~mm}$ diam in fruit; basal bract leafy, broadly ovate, $5-25$ by $5-20 \mathrm{~mm}$, soon falling, upper bract scale-like, broadly ovate-triangular, 1-2 mm long; sepals broadly ovate-triangular, 3-8 by $3-6 \mathrm{~mm}$, verruculose, spreading to reflexed; petals green, maturing yellow, subequal, inner ones slightly narrower than the outer ones, narrowly triangular, $15-35$ by $3-9 \mathrm{~mm}$, margins revolute. Monocarps 5-30, green, yellow, orange, maturing red and finally purple-black, spherical to oblongoid-ellipsoid, 7-21 by 7-16 mm, glabrous, apex rounded, slightly constricted between the seeds upon drying, wall $0.3-0.5 \mathrm{~mm}$ thick, stipes $10-27$ by $0.5-1 \mathrm{~mm}$. Seeds $1-5$, in one row, spherical, discoid or hemispherical, $7-13$ by 2-5 mm, grooved.

Distribution - Costa Rica, Panama.

Habitat \& Ecology — In lower montane or premontane wet forests. At elevations of 600-2000 m. Flowering: all year through; fruiting: all year through.

Vernacular names - Not recorded.

Field observations - 'Old flowers emit strong banana smell' (Mori \& Kallunki 5317, Panama); 'flores muy aromaticas' (Rodríguez et al. 11801, Costa Rica).

Note - Desmopsis maxonii is recognizable by its mostly completely glabrous vegetative parts, usually very long pedicels (to $110 \mathrm{~mm}$ long) bearing a leafy lower bract, and often many monocarps (to 30 ) borne on relatively long and slender stipes (10-22 by $0.5-1 \mathrm{~mm})$.

\section{Desmopsis mexicana R.E.Fr. - Map 6}

Desmopsis mexicana R.E.Fr. (1948) 14, t. 6c, d. - Type: Hinton 15836 (holo US; iso K 2 sheets, LL, MICH, NY, UC), Mexico, Michoacan, Distr. Coalcoman, Aquila, shady barranca, 21-24 Mar. 1941.

Shrub or tree 2-5 m tall, diam not recorded; young twigs and petiole rather densely covered with brown, appressed hairs. Leaves: petiole 3-5 $\mathrm{mm}$ long, 1-2 $\mathrm{mm}$ diam; lamina elliptic, $7-15$ by $3-6 \mathrm{~cm}$, chartaceous, shiny and glabrous above, soon glabrous below, but sparsely covered with appressed hairs mainly along primary vein, base obtuse to rounded, rarely acute, apex obtuse to acute to rarely acuminate, the extreme tip rounded, primary vein impressed above, secondary veins 6-10 on either side of primary vein, raised above, tertiary veins raised above, reticulate. Inflorescence and flower indument: pedicels and outer side of bracts, sepals, and petals sparsely to densely covered with appressed hairs. Inflorescences 1- or 2-flowered, leaf-opposed; pedicels 20-35 mm long, 0.5-1 mm diam; basal bract scale-like, broadly ovate-triangular, c. 1 by $1 \mathrm{~mm}$, upper bract scale-like, 1 by $0.8 \mathrm{~mm}$; sepals broadly ovate-triangular, $1-1.5$ by $1-1.5 \mathrm{~mm}$, soon reflexed; petals green, subequal, narrowly oblong-linear, $10-25$ by $2-4 \mathrm{~mm}$, margins slightly revolute. Monocarps 3-11, red, spherical to obovoid, 10-18 by $8-10 \mathrm{~mm}$, apex rounded, slightly constricted between the seeds upon drying, sparsely covered with appressed hairs to glabrous, wall c. $0.2 \mathrm{~mm}$ thick, stipes $3-5$ by $1 \mathrm{~mm}$. Seeds 1 or 2 , in one row, spherical to ellipsoid or hemispherical, c. 10 by $8 \mathrm{~mm}$, smooth to slightly pitted.

Distribution - Mexico (Michoacan).

Habitat \& Ecology — In semi-evergreen forest. At elevations of 220-250 m. Flowering: March; fruiting: March.

Vernacular names - Not recorded.
Note - Desmopsis mexicana can be recognized by its leaves with an obtuse to rounded base and usually obtuse apex, the extreme tip rounded, scale-like bracts on the pedicel, very small and reflexed sepals (1-1.5 by $1-1.5 \mathrm{~mm}$ ), and 1 - or 2-seeded monocarps borne on relatively short stipes (3-5 $\mathrm{mm}$ long).

\section{Desmopsis microcarpa R.E.Fr. - Map 7}

Desmopsis microcarpa R.E.Fr. (1930) 23, f. 3c. - Type: Pittier 16014 (holo $\mathrm{B}$; iso $\mathrm{F}, \mathrm{GH}, \mathrm{K}, \mathrm{NY}, \mathrm{Z})$, Costa Rica, 'le long de la côte entre Limon et Moin', Sept. 1899.

Desmopsis glabrata Schery in Woodson \& Schery (1941) 428. - Type: Von Wedel 279 (holo MO), Panama, Bocas del Toro, vicinity of Bocas del Toro, alt. near sea level, 1 Aug. 1940.

Shrub or tree 2-8 $\mathrm{m}$ tall, diam not recorded; young twigs and petiole rather densely to sparsely covered with appressed hairs, soon glabrous. Leaves: petiole 4-10 mm long, 1-2 mm diam; lamina narrowly elliptic to elliptic, $6-25$ by $2-9 \mathrm{~cm}$, chartaceous, both sides often verruculose, shiny and glabrous above, except for erect hairs along primary vein, subglabrous below, base acute to obtuse, or slightly attenuate, apex acuminate (acumen 5-25 mm long), the extreme tip obtuse, primary vein slightly impressed above, secondary veins $6-10$ on either side of primary vein, slightly raised above, tertiary veins raised above, reticulate. Inflorescence and flower indument: pedicels sparsely covered with appressed hairs to glabrous, outer side of bracts, sepals and petals sparsely to rather densely covered with appressed hairs. Inflorescences 1-flowered, leaf-opposed; pedicels $20-100 \mathrm{~mm}$ long, $0.5-1 \mathrm{~mm}$ diam, to c. $2 \mathrm{~mm}$ diam in fruit; basal bract leafy, broadly obovate to circular, 5-20 by $4-20 \mathrm{~mm}$, upper bract leafy, broadly ovate-triangular, $2-5$ by $2-5 \mathrm{~mm}$, or scale-like; sepals with distinct venation, broadly ovate-triangular, $5-15$ by $4-10 \mathrm{~mm}$, reflexed; petals yellow, subequal, black in sicco, narrowly triangular, $20-40$ by 5-12 mm, apex incurved. Monocarps 10-25, green, maturing yellow, orange, red, to black, ellipsoid to oblongoid-ellipsoid, 7-30 by $6-18 \mathrm{~mm}$, sparsely covered with appressed hairs, soon glabrous, apex rounded, slightly constricted between the seeds upon drying, wall c. $0.5 \mathrm{~mm}$ thick, stipes $7-25 \mathrm{~mm}$ long, 0.5-1 mm diam. Seeds 1-5, in one row, spherical, discoid or hemispherical, $7-13$ by $2-5 \mathrm{~mm}$, strongly grooved, pitted.

Distribution - Nicaragua, Costa Rica, Panama.

Habitat \& Ecology — In wet, evergreen, tropical rain forests or premontane forests. At elevations of 0-1400 m. Flowering: January to August, November; fruiting: all year through.

Vernacular names - Nicaragua: Palanco (Salick 8046), Uva (Rueda et al. 2685).

Field observations - 'Flores con olor a banano' (Chávez 532, Costa Rica); 'flowers full of staphilinid beetles' (Chatrou et al. 96, Costa Rica); 'flowers exhaling an aroma of green apples or ripe bananas' (Grayum et al. 7700, Costa Rica); 'flowers fragrant' (Penneys et al. 300, Costa Rica); 'wood used for houses' (Salick 8046, Nicaragua).

Note - Desmopsis microcarpa differs from D. bibracteata by various features:

1. The leaf apex is acuminate (acumen $5-25 \mathrm{~mm}$ long) in D. microcarpa vs acute to shortly acuminate with the extreme tip distinctly rounded in D. bibracteata (acumen to c. $5 \mathrm{~mm}$ long).

2. In $D$. microcarpa the sepals are larger (5-15 $\mathrm{mm}$ long vs 2-4 $\mathrm{mm}$ in D. bibracteata).

3. In $D$. microcarpa the petals $(20-40 \mathrm{~mm}$ long) are acute, thin and black in sicco whereas in $D$. bibracteata the petals (11-25 $\mathrm{mm}$ long) are distinctly rounded at the extreme tip, thicker and brown in sicco. 


\section{Desmopsis neglecta (A.Rich.) R.E.Fr. — Map 8}

Desmopsis neglecta (A.Rich.) R.E.Fr. (1927) 3. - Uvaria neglecta A.Rich. (1841 '1845') 44. - Type: de la Sagra s.n. (holo P), Cuba, 'Crescit frequens in sylvis diversarum insulae partium, et specialiter in parte occidentali'

Asimina rhombifolia Griseb. (1866) 4. - Type: Wright 1852 (lecto GOET, selected here; isolecto $\mathrm{B}, \mathrm{BM}, \mathrm{G} 3$ sheets, $\mathrm{GH}, \mathrm{HAC}, \mathrm{K}, \mathrm{MA}, \mathrm{MO}, \mathrm{NY} 2$ sheets, $\mathrm{P}, \mathrm{S} 2$ sheets, US), Cuba, Pinar del Río, Viñales ('in collibus pr. S. José'), 30 June 1860-1864.

Shrub or tree 1-2 m tall, diam not recorded; young twigs and petiole rather densely covered with erect, brownish hairs. Leaves: petiole 1-4 $\mathrm{mm}$ long, c. $1 \mathrm{~mm}$ diam; lamina broadly rhombic-obovate to circular, $2-8$ by $1.5-5 \mathrm{~cm}$, subcoriaceous, margins slightly revolute, shiny and glabrous on both sides, but with some soon falling erect hairs along primary vein below, base acute to obtuse, slightly oblique, apex acuminate (acumen 5-20 mm long), the extreme tip obtuse to rounded, often curved to one side, primary vein slightly impressed above, secondary veins $5-13$ on either side of primary vein, raised above, tertiary veins raised above, reticulate. Inflorescence and flower indument: pedicels and outer side of bracts, sepals densely covered with erect and appressed hairs, petals rather densely covered with appressed hairs. Inflorescences 1 - or 2-flowered, leaf-opposed, pedicels 5-10 mm long, c. $1 \mathrm{~mm}$ diam, to c. $15 \mathrm{~mm}$ long in fruit, basal and upper bracts at nearly the same level, scale-like, broadly ovate-triangular, $1-2$ by 1-2 $\mathrm{mm}$; sepals broadly ovate-triangular, $1-2.5$ by $1-2.5 \mathrm{~mm}$; petals subequal, linear, $13-19$ by $3-5 \mathrm{~mm}$. Monocarps $6-15$, colour not recorded, ellipsoid, to c. 20 by $15 \mathrm{~mm}$, densely covered with brown, erect and appressed hairs when young, finally glabrous, apex rounded, not constricted between the seeds upon drying, wall c. $0.5 \mathrm{~mm}$ thick, stipes $0-3 \mathrm{~mm}$ long, c. $1 \mathrm{~mm}$ diam. Seeds 2 , in one row, hemispherical, $8-13$ by $8 \mathrm{~mm}$, smooth.

Distribution - Cuba (Pinar del Río).

Habitat \& Ecology - In tropical moist gallery forests. Presumably at low elevation. Flowering: June; fruiting: June.

Vernacular names - Not recorded.

Note - Desmopsis neglecta is very peculiar in being the only species of the genus occurring in the Caribbean on Cuba. It is distinguished by its small, almost rhombic leaves, short pedicels bearing scale-like bracts at nearly the same level, and subsessile monocarps.

\section{Desmopsis nigrescens G.E.Schatz, sp. nov. - Fig. 2d,} 3b; Map 2

Desmopsis nigrescens is recognized by its relatively large glabrous lamina $(15-30$ by $5-14 \mathrm{~cm})$ that dry black, relatively long pedicels $(20-60 \mathrm{~mm}$ long, to c. $80 \mathrm{~mm}$ in fruit) bearing a large, leafy basal bract and scale-like upper bract, and relatively large sepals $(4-10$ by $3-6 \mathrm{~mm}$ ) that are accrescent (expanding to 22 by $14 \mathrm{~mm}$ ) and often persistent in fruit. - Type: Liesner 1038 (holo MO; iso F, NA, NY), Panamá, Colón, 10 mi SW of Portobelo, 2-4 mi from coast, 10-200 m, 24 Mar. 1973.

Tree 2-12 m tall, c. $6 \mathrm{~cm}$ diam; young twigs and petioles glabrous. Leaves: petiole 3-11 $\mathrm{mm}$ long, 2-3 $\mathrm{mm}$ diam; lamina generally drying black, narrowly elliptic to elliptic, sometimes narrowly obovate, $15-30$ by $5-14 \mathrm{~cm}$, coriaceous, glabrous above, glabrous below, except for some scattered hairs along primary vein, base acute to obtuse, apex acuminate (acumen 10-25 mm long), primary vein impressed above, secondary veins $9-12$ on either side of primary vein, raised above, tertiary veins raised above, reticulate. Inflorescence and flower indument: outer side of bracts glabrous, pedicels and outer side of sepals sparsely to rather densely covered with brown, curly hairs, outer side of petals rather densely to sparsely covered with appressed hairs. Inflorescences 1- or 2-flowered, leafopposed; pedicels $20-60 \mathrm{~mm}$ long, c. $1 \mathrm{~mm}$ diam, to c. 80 $\mathrm{mm}$ long and $1-3 \mathrm{~mm}$ diam in fruit; basal bract leafy, broadly

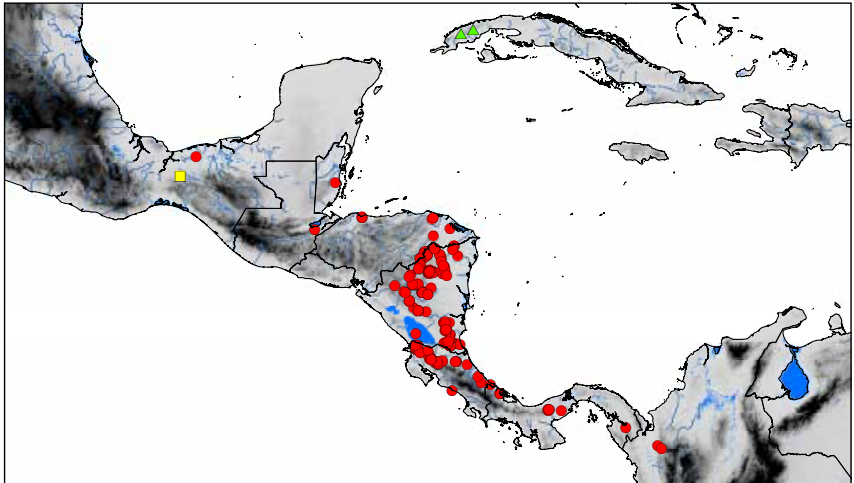

Map 8 Distribution of Desmopsis neglecta (A.Rich.) R.E.Fr. ( $\mathbf{\Delta})$, D. schippii Standl. (O) and D. wendtii G.E.Schatz (ם).

ovate, $15-50$ by $10-50 \mathrm{~mm}$, upper bract scale-like, broadly ovate-triangular, c. $1 \mathrm{~mm}$ long; sepals ovate-triangular, 4-10 by $3-6 \mathrm{~mm}$ at anthesis, accrescent and often persistent in fruit, expanding to c. 22 by $14 \mathrm{~mm}$; petals pale green, maturing yellow, subequal, narrowly triangular, $17-25$ by $4-6 \mathrm{~mm}$. Monocarps 10-25, green, yellow, yellow-orange, orange, to red-black, oblongoid-ellipsoid to subspherical, $9-25$ by $8-15$ $\mathrm{mm}$, glabrous, apex rounded, slightly constricted between the seeds upon drying, wall $0.5-1 \mathrm{~mm}$ thick, stipes $7-35 \mathrm{~mm}$ long, 1-2 mm diam. Seeds 2-6, in one row, discoid or hemispherical, $7-12$ by $2-5 \mathrm{~mm}$, strongly grooved.

Distribution - Panama.

Habitat \& Ecology - In primary rain forests. At elevations of 0-750 m. Flowering: January to May; fruiting: January to March, June, July, November.

Vernacular names - Not recorded.

Other specimens examined. PANAmA, Coclé, area between Caño Blanco del Norte, Caño Sucio and Chorro del Río Tife, 200-400 m, Davidse \& Hamilton 23556 (MO); El Valle, 800-1000 m, Duke 13184 (MO); La Pintada, Parque Nacional G.D. Omar Torrijos, 158 m, Martínez 1354 (PMA); between Río Blanco and Caño Susio $1 \mathrm{hr}$ hike to the west, Río Blanco is c. $5 \mathrm{hr}$ hike north down from the continental Divide above El Copé and EI Petroso sawmill, 350-400 ft, Sytsma et al. 2491 (MO). Colón, Proyecto Minero Cobre Panama, 116 m, Batista 304 (PMA); en la carretera a la zona de Santa Rita, Correa et al. 1822 (PMA); San Juan del General, de Gracia 779 (MO); East Ridge, Duke 15278 (MO); Donoso, helipat C02, 124 m, Espinosa 5711 (MO); Donoso, Belen, 47 m, Espinosa 5963 (MO); Río Buenaventura, near Portobello, Foster 1694 (DUKE); Aguacate, 0-200 ft, Hammel 4433 (MO, U); Teck Cominco Petaquilla mining concession, 184 m, McPherson 19564 (MO, PMA, WAG), idem, $11 \mathrm{~m}$, McPherson 20042 (MO), idem, $300 \mathrm{~m}$, McPherson 20610 (MO, PMA, WAG), idem, 50 m, McPherson 20636 (MO, PMA, WAG); Río Guanche, Mori \& Kallunki 3013 (MO); Santa Rita Ridge Road, 18-20 km from Transisthmian Hwy, 100-1200ft, Sytsma 2042 (MO); Cerro La Gloria, Nombre de Dios, Valdespino et al. 432 (PMA, U); Teck Cominco Petaquilla mining concession, $296 \mathrm{~m}$, van der Werff \& McPherson 22210 (MO, WAG). Panama, Cerro Jefe region, c. 1.5 miles along Río Pacora road from junction with Cerro Jefe road, $750 \mathrm{~m}$, McPherson \& Merello 8129 (MO, U). San Blas, 12 miles from Pan-American Highway on Cartí Road, $1100 \mathrm{ft}$, Antonio 4850 (MO, U); El Llano-Cartí road, km 12.2, 350 m, De Nevers \& Herrera 4348 (MO, PMA), Km 26.5, De Nevers et al. 5281 (MO); trail to Cerro Óbu (Habu of maps) from Río Urgandi (Río Sidra), 100-300 m, De Nevers et al. 7976 (MO); road from El Llano to Cartí, Pacific side, 200-300 m, Hamilton \& Stockwell 2940 (MO); 8.2 miles from the Pan-American Highway on the El Llano-Cartí road, 450 m, Knapp 5899 (MO); along El Llano-Cartí-Tupile road, 10-12 km N of the Interamerican Hwy, $500 \mathrm{~m}$, Luteyn \& Wilbur 4659 (DUKE, F, MO); boundary trail on Llano-Cartí road, $350 \mathrm{~m}$, McPherson \& Merello 8168 (MO); near El Llano-Cartí road, NW of Nusagandi on Sendero Wedar, 150-250 m, McPherson 11054 (MO, U); El Llano-Cartí Road, 5 miles from highway, $350 \mathrm{~m}$, McPherson 11281 (MO). Veraguas, along banks of first river on road between Alto Piedra School and Río Colovebora, 1.8 miles beyond School, 500 m, Croat 34104 (MO).

Note - Desmopsis nigrescens is very well marked by its large leaves $(15-30$ by $5-14 \mathrm{~cm}$ ) drying black (hence the specific name), and relatively large sepals (to 22 by $14 \mathrm{~mm}$ in 
fruit) which are often persistent in fruit. It might be confused with $D$. maxonii, which, however, has smaller, non-accrescent sepals ( $3-8$ by $3-6 \mathrm{~mm}$ ) that are not persistent in fruit. Moreover, $D$. nigrescens occurs at lower elevations $(0-750 \mathrm{~m})$ than D. maxonii (600-2000 m).

\section{Desmopsis oerstedii Saff. — Map 2}

Desmopsis oerstedii Saff. (1916) 191. - Type: Oersted 148 (holo C; iso S (fragment), US 2 sheets, W), Costa Rica, Alajuela, 'auf dem Berg Aguacate', Nov. 1847.

Shrub or tree 2-10 m tall, c. $15 \mathrm{~cm}$ diam; young twigs and petiole densely covered with long-persisting, brownish, erect hairs (velutinous) $0.2-0.3 \mathrm{~mm}$ long. Leaves: petiole $4-7 \mathrm{~mm}$ long, c. $1 \mathrm{~mm}$ diam; lamina narrowly elliptic to elliptic, 5-14 by 3-6 cm, chartaceous, glossy and glabrous above, except for erect hairs along primary vein, densely covered with longpersisting, brownish, erect hairs (velutinous) $0.2-0.4 \mathrm{~mm}$ long below, base acute, apex acute to acuminate (acumen 5-10 mm long), primary vein impressed above, secondary veins $8-11$, slightly raised above, tertiary veins flat to slightly raised above, reticulate. Inflorescence and flower indument: pedicels and outer side of bracts densely covered with brownish, erect hairs (velutinous) $0.2-0.3 \mathrm{~mm}$ long. Inflorescence: flowers not seen. Infructescence bearing 1 fruit, leaf-opposed; fruiting pedicels 20-40 mm long, c. $2 \mathrm{~mm}$ diam; basal bract leafy, broadly ovate to ovate, $7-25$ by $5-15 \mathrm{~mm}$, upper bract leafy, ovate-triangular, 3-6 by 2-4 mm. Monocarps 5-10, yellow, maturing purplered, ellipsoid to subspherical, $15-30$ by $10-20 \mathrm{~mm}$, sparsely covered with erect hairs c. $0.1 \mathrm{~mm}$ long, soon glabrous, base attenuate, apex rounded, not constricted between seeds upon drying, wall 2-4 mm thick, stipes 5-12 $\mathrm{mm}$ long, 2-4 mm diam. Seeds $3-5$, in one row, discoid or hemispherical, $8-11$ by $2-3$ $\mathrm{mm}$, grooved to slightly pitted.

Distribution - Costa Rica (Alajuela, San José).

Habitat \& Ecology — In mid-altitude evergreen forests. At elevations of 700-1300 m. Flowering: unknown; fruiting: October to December.

Vernacular names - Not recorded.

Note - Desmopsis oerstedii is easily recognizable by the combination of a long-persisting indument of erect hairs on young twigs and lower side of the leaves, and large, thick-walled monocarps (wall 2-4 $\mathrm{mm}$ thick) with an attenuate base borne on relatively thick stipes (2-4 $\mathrm{mm}$ diam).

\section{Desmopsis panamensis (B.L.Rob.) Saff. - Map 3}

Desmopsis panamensis (B.L.Rob.) Saff. (1916) 185, pl. 7. - Unona panamensis B.L.Rob. (in Robinson \& Greenman 1895) 175. - Type: Hayes s.n. (468 in some duplicates) (holo $\mathrm{GH}$; iso EAP, F, GH, K, NY 2 sheets, S 2 sheets, US 3 sheets, VT), Panama, 'woods near Gatún Station on the old Panama Railway', 20-30 m, 30 Jan. 1860.

Tree or shrub 2-15 m tall, diam not recorded; young twigs and petiole densely covered with erect and some appressed, brown to white, often curly hairs. Leaves: petiole 2-6 mm long, 1-2 $\mathrm{mm}$ diam; lamina narrowly elliptic, $10-20$ by $4-8 \mathrm{~cm}$, chartaceous, glabrous, but primary vein mostly covered with erect hairs above, sparsely covered with appressed and erect, often curly hairs below, the primary vein mostly densely so, base acute to obtuse, apex acuminate (acumen 5-10 mm long), the extreme tip obtuse, primary vein impressed above, secondary veins $8-12$ on either side of primary vein, slightly raised above, tertiary veins slightly raised to flat above, reticulate. Inflorescence and flower indument: pedicels and outer side of bracts, sepals, and petals rather densely covered with erect and appressed hairs. Inflorescences 1-6-flowered, leafopposed; pedicels $30-70 \mathrm{~mm}$ long, c. $1 \mathrm{~mm}$ diam, to c. $100 \mathrm{~m}$ long and 1.5-2 mm diam in fruit; basal bract leafy, broadly ovate to circular, $3-42$ by $2-26 \mathrm{~mm}$, upper bract scale-like, broadly ovate-triangular, $1-3 \mathrm{~mm}$ long; sepals ovate-triangular to broadly so, $2-5$ by $2-5 \mathrm{~mm}$, sometimes reflexed; petals yellow, subequal, narrowly triangular, $8-31$ by $3-7 \mathrm{~mm}$, margins strongly revolute, apex incurved. Monocarps 5-25, green, maturing orange, red to purple, ellipsoid-oblongoid to spherical, $10-30$ by $9-16 \mathrm{~mm}$, glabrous, occasionally rather densely covered with long-persisting, appressed and erect, white, curly hairs, apex rounded, sometimes slightly constricted between the seeds upon drying, wall $0.2-0.5 \mathrm{~mm}$ thick, stipes 5-12 mm long, 1-1.5 mm diam. Seeds 2-7, in one row, discoid or hemispherical, $6-11$ by $2-5 \mathrm{~mm}$, slightly grooved and pitted.

Distribution - Panama (Panama, Veraguas).

Habitat \& Ecology - In lowland rain forests. At elevations of 0-800 m. Flowering: September to April; fruiting: all year through.

Vernacular name - Panama: Anonilla.

Field observations - 'Fruit eaten by white-faced monkeys' (Croat 1978: 401, Panama).

Notes - Desmopsis panamensis is characterized by a brown to white indument of appressed and erect more or less curly hairs on the young twigs, small sepals (2-5 mm long), and relatively long pedicels (30-100 $\mathrm{mm}$ long).

On Barro Colorado Island the monocarps have a rather longpersisting indument.

\section{Desmopsis schippii Standl. - Fig. 3d; Map 8}

Desmopsis schippii Standl. (1932) 130. - Type: Schipp 960 (holo F; iso A, BM, F, G, GH, K, MICH, MO, NY, UC, Z), Belize, Nineteen Mile, Stann Creek Valley, along creek bank in forest, 75 m, 28 June 1932.

Desmopsis brevipes R.E.Fr. (1941) 107. - Type: Standley \& Valerio 44576 (holo US; iso S (fragment)), Costa Rica, Guanacaste, Tilarán, El Silencio, moist forest, 13 Jan. 1926.

Tree or shrub 1.5-20 m tall, 5-30 cm diam; young twigs glabrous or sparsely covered with appressed hairs. Leaves: petiole 2-8 mm long, 1-2 mm diam; lamina narrowly elliptic to elliptic, $8-22$ by $3-9 \mathrm{~cm}$, chartaceous, glabrous above, glabrous, but sparsely covered with appressed hairs along the primary vein below, base acute to obtuse, rarely attenuate, apex acute to acuminate (acumen 5-20 mm long), the extreme tip obtuse, primary vein impressed above, secondary veins $6-8$ on either side of primary vein, slightly raised above, tertiary veins slightly raised above, reticulate. Inflorescence and flower indument: pedicels and outer side of bracts, sepals, and petals sparsely to densely covered with appressed hairs. Inflorescences 1- or 2-flowered, leaf-opposed, sometimes produced from the main trunk; pedicels $10-80 \mathrm{~mm}$ long, $0.5-1 \mathrm{~mm}$ diam, $1-2 \mathrm{~mm}$ diam in fruit; basal and upper bracts scale-like, broadly ovatetriangular, 1-2 mm long; sepals broadly ovate-triangular, 1-3 by $1.5-4 \mathrm{~mm}$, spreading; petals green, maturing yellow, subequal, narrowly triangular to linear, $15-45$ by $4-6 \mathrm{~mm}$, apex often incurved, margins revolute. Monocarps 2-8(-11), green, maturing red to purple-black, pulp orange, spherical, broadly ellipsoid, less often oblongoid-ellipsoid, $10-27$ by $10-25 \mathrm{~mm}$, rather densely to sparsely covered with appressed hairs, soon glabrous, apex rounded, rarely slightly constricted between the seeds upon drying, wall $0.5-1 \mathrm{~mm}$ thick, stipes $1-5 \mathrm{~mm}$ long, 1-3 mm diam. Seeds 1-4, in one row, spherical, discoid or hemispherical, $8-15$ by $3-5 \mathrm{~mm}$, strongly grooved.

Distribution - Mexico (Tabasco), Belize, Guatemala, Honduras, Nicaragua, Costa Rica, Panama, and Colombia.

Habitat \& Ecology — In lowland, evergreen or premontane forests. At elevations of 0-1400 m. Flowering: all year through; fruiting: all year through. 
Vernacular names - Guatemala: Anona. Nicaragua: Anono (Rueda et al. 3779), Botín de reina (Little 25180), Canjura (Grijalva 3776), Palanca (Sandino 3349), Palanco (Rueda \& Coronado 6461).

Field observations - 'Flowers with peculiar 'plastic' scent' (Nee \& Vega 27898, Nicaragua); 'pulp of fruits orange and sweet' (W.D. Stevens 4783, Nicaragua); 'flores aromáticas' (G. Herrera 2066, Costa Rica).

Note - Desmopsis schippii is distinguished by a low number $(2-5)$ of shortly stipitate (1-5 mm long) monocarps, minute bracts, short sepals (1-3 mm long), and the almost complete absence of hairs on the vegetative parts. Material from Costa Rica tends to have relatively shorter pedicels.

\section{Desmopsis subnuda (R.E.Fr.) G.E.Schatz \& Maas, comb. nov. - Fig. 3e; Map 6}

Desmopsis subnuda (R.E.Fr.) G.E.Schatz \& Maas, comb. nov. - Desmopsis galeottiana (Baill.) Saff. var. subnuda R.E.Fr. (1930) 22. - Type: Liebmann 4 (holo C), Mexico, Veracruz, Mirador, Oct. 1841.

Tree or shrub 1-12 m tall, 7-10 cm diam; young twigs and petiole densely to sparsely covered with brown, appressed hairs, soon glabrous. Leaves: petiole 2-10 mm long, c. $1 \mathrm{~mm}$ diam; lamina elliptic or narrowly so, sometimes ovate, $7-12$ by $2.5-6 \mathrm{~cm}$, chartaceous, shiny and glabrous above, but the primary vein often covered with appressed or erect hairs, glabrous below, except for appressed hairs along primary vein, base obtuse, acute, sometimes attenuate, rarely cordate, apex bluntly acute, primary vein impressed to flat above, secondary veins $5-10$ on either side of primary vein, slightly raised above, tertiary veins slightly raised above, reticulate. Inflorescence and flower indument: pedicels and outer side of bracts, sepals, and petals sparsely to rather densely covered with appressed hairs to glabrous. Inflorescences 1- or 2-flowered, leaf-opposed, occasionally produced from the main trunk; flowering and fruiting pedicels $15-50 \mathrm{~mm}$ long, $0.5-1 \mathrm{~mm}$ diam; basal bract leafy or less often scale-like, broadly ovate-triangular, $1-25$ by $1-15 \mathrm{~mm}$, upper bract scalelike to sometimes leafy, broadly ovate, $1-7$ by $1-7 \mathrm{~mm}$; sepals broadly ovate-triangular, $3-6$ by $3-5 \mathrm{~mm}$, spreading; petals greenish yellow to yellow, subequal, sometimes distinctly veined, ovate-triangular or narrowly so, $9-20$ by $3-7 \mathrm{~mm}$. Monocarps $2-8$, green, maturing red, pulp yellow to orange, spherical, ellipsoid to oblongoid-ellipsoid, $8-17$ by $8-15 \mathrm{~mm}$, sparsely covered with appressed hairs, soon glabrous, apex rounded, sometimes slightly constricted between the seeds upon drying, wall 0.3-0.5 $\mathrm{mm}$ thick, stipes 3-7 mm long, c. $1 \mathrm{~mm}$ diam. Seeds $1-4$, in one row, spherical, discoid or hemispherical, c. 8 by $4-5 \mathrm{~mm}$, grooved, slightly pitted.

Distribution - Mexico (Oaxaca, Veracruz).

Habitat \& Ecology - In deciduous and evergreen forest with Bernoullia sp., Brosimum sp., Bursera simaruba, Calophyllum sp., Cedrela sp., Dialium sp., Ficus sp., Manilkara sp., Poulsenia sp., Pouteria sapota, Robinsonella mirandae, Spondias sp., Stemmadenia donnellsmithii, Schizolobium sp., Tapirira sp., Terminalia sp., and Vatairea sp., often on rocky soil. At elevations of $0-1050 \mathrm{~m}$. Flowering: March to December; fruiting: all year through.

Vernacular names - Not recorded.

Field observations - 'Flor con olor a anona verde' (Hernández G. 116, Mexico).

Notes - Whereas D. galeottiana (Baill.) Saff. (basionym: Trigynaea galeottiana Baill. typified by Liebmann 7) is considered a synonym of $D$. trunciflora, the taxon $D$. galeottiana var. subnuda described by Fries (1931) is typified by Liebmann 4, and is here considered to represent a distinct species for which the combination $D$. subnuda is proposed.
Desmopsis subnuda is characterized by glabrous leaves (except for appressed hairs along the primary vein), the presence of usually two leafy bracts, sepals $3-6 \mathrm{~mm}$ long, 2-8 monocarps, the wall of the monocarps $0.3-0.5 \mathrm{~mm}$ thick, and stipes 3-7 mm long.

\section{Desmopsis talamancana G.E.Schatz \& Maas, sp. nov. -} Fig. 4a; Map 7

Desmopsis talamancana is recognized by its relatively small, glabrous leaves (5-9 by $2-5 \mathrm{~cm}$ ), and a small number (5) of large monocarps (20-30 by 14-20 mm) with seeds in two rows. - Type: Aguilar \& Jiménez Madrigal 4317 (holo MO; iso INB, U), Costa Rica, Puntarenas, Cantón de Buenas Aires, R.I. Ujarrás, Cordillera de Talamanca, Reserva Biológica Dúrika, 1500 m, 6 Sept. 1995.

Tree 4-7 m tall, diam not recorded; young twigs and petiole sparsely covered with appressed hairs, very soon glabrous. Leaves: petiole $3-5 \mathrm{~mm}$ long, $0.5-1 \mathrm{~mm}$ diam; lamina narrowly elliptic, $5-9$ by $2-5 \mathrm{~cm}$, chartaceous, verruculose below, dull (but 'brillantes' in vivo), greenish above, greenish below, glabrous above, except for some hairs along the primary vein above, glabrous below, base attenuate, apex acute to acuminate (acumen c. $5 \mathrm{~mm}$ long), primary vein strongly impressed above, secondary veins indistinct, $6-10$ on either side of primary vein, flat to slightly raised above, smallest distance between loops and margin 1-2 $\mathrm{mm}$, tertiary veins flat to slightly raised above, reticulate. Inflorescence and flower indument: outer side of bracts and pedicels sparsely covered with appressed hairs to glabrous. Inflorescence: flowers not seen. Infructescence bearing 1 fruit, leaf-opposed; fruiting pedicels $30-40 \mathrm{~mm}$ long, 1-2 $\mathrm{mm}$ diam; basal bract leafy, ovate, $10-15$ by $8-10 \mathrm{~mm}$, usually absent in fruit, upper bract scale-like, 1-1.5 mm long. Monocarps c. 5, green, maturing orange in vivo, black in sicco, ellipsoid to slightly ovoid, $20-30$ by $14-20 \mathrm{~mm}$, sparsely covered with appressed hairs when young, soon glabrous, apex rounded, not constricted between seeds upon drying, wall 1-1.5 $\mathrm{mm}$ thick, stipes 3-7 mm long, 2-3 mm diam. Seeds c. 10, in two rows, hemidiscoid or quartispherical, 10 by $3-5 \mathrm{~mm}$, pale brown, slightly grooved.

Distribution - Costa Rica.

Habitat \& Ecology - In submontane forest. At elevations of 1450-1500 m. Flowering: not recorded; fruiting: September.

Vernacular names - Not recorded.

Other specimen examined. CostA RICA, Puntarenas, Cantón de Buenas Aires, Ujarrás, cabeceras de Río Kuiyé, siguiendo las Filas que dan a Olán, 1450 m, 20 Sept. 1989, G. Herrera 3498 (U 2 sheets).

Note - Desmopsis talamancana can be distinguished by its relatively small $(5-9$ by $2-5 \mathrm{~cm})$, glabrous leaves with an attenuate base and acuminate apex, a leafy lower bract on the pedicel, and fruits with seeds in two rows. Its leaves are much smaller than other species with biseriate ovules, and it occurs at much higher elevation in Costa Rica than $D$. biseriata and D. heteropetala.

22. Desmopsis trunciflora (Schltdl. \& Cham.) G.E.Schatz Map 5

Desmopsis trunciflora (Schltdl. \& Cham.) G.E.Schatz (1994) 419. - Xylopia trunciflora Schltdl. \& Cham. (1831) 417. - Xylopicrum trunciflorum (as 'truncifolium') (Schltdl. \& Cham.) Kuntze (1891) 8. - Unonopsis trunciflora (Schltdl. \& Cham.) R.E.Fr. (1900) 27. - Type: Schiede 1287 (holo B; iso BM, HAL), Mexico, 'Inter Colipam et litora maris. Reg. cal. Mart.', Mar. 1829. Annona ? bibracteata Hook. (1841) t. 328. - Guatteria bibracteata (Hook.) Hemsl. (1878) 1. - Type: Galeotti 7083 (holo G), Mexico, Veracruz, Xalapa. Trigynaea (as 'Trigyneia') galeottiana Baill. (1868) 181. — Unonopsis galeottiana (Baill.) R.E.Fr. (1900) 28. - Desmopsis galeottiana (Baill.) Saff. (1916) 187. - Type: Liebmann 7 (lecto, designated by Safford (1916), C; iso P 2 sheets), Mexico, Veracruz, Palenque, Mar. 1841. 


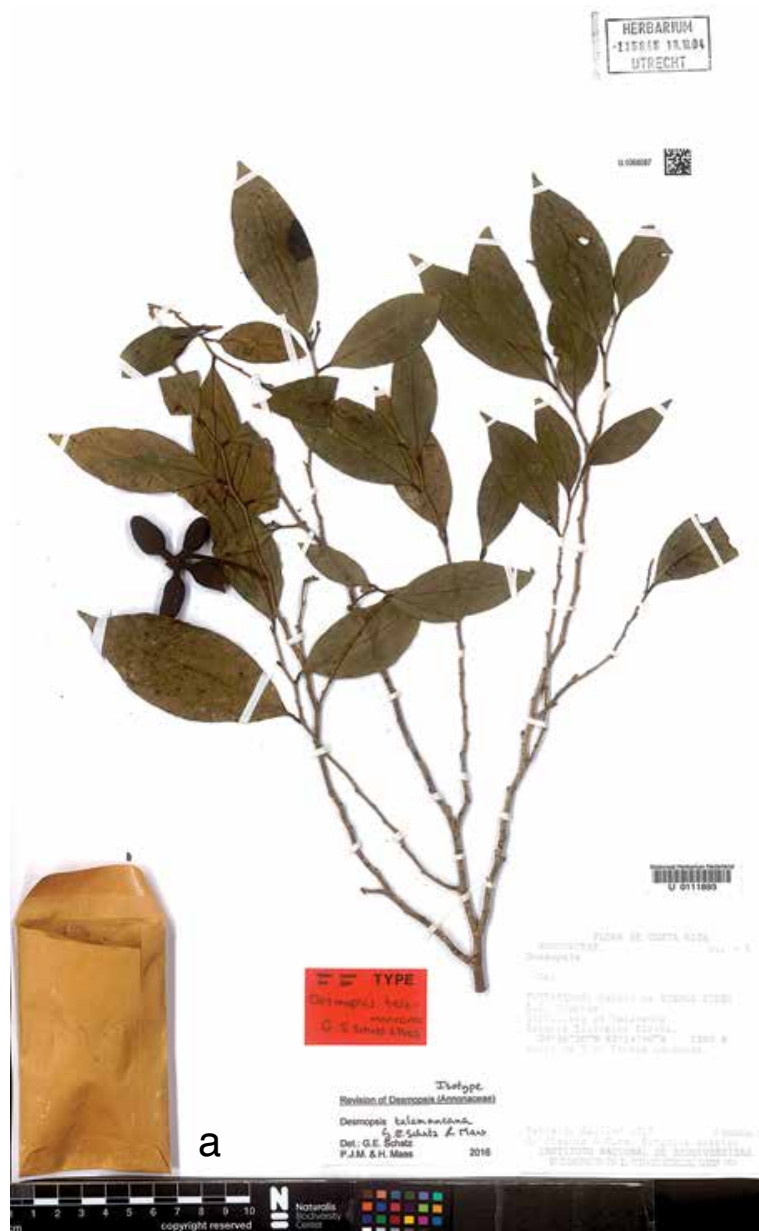

b

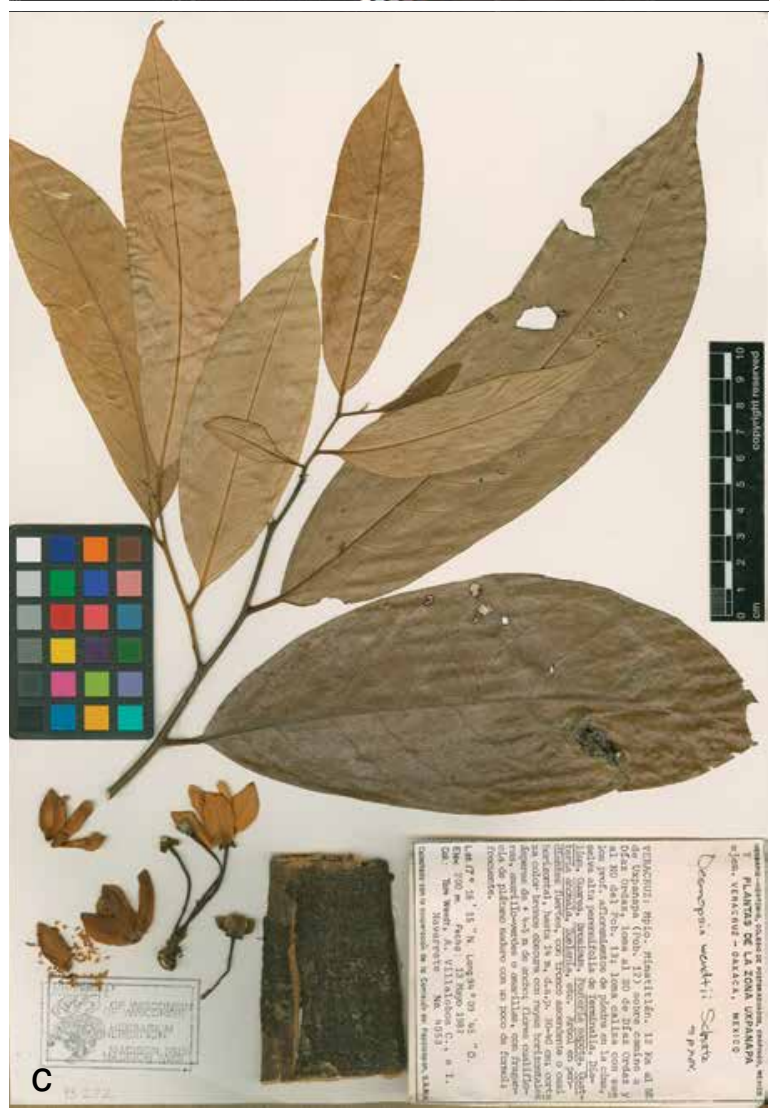

Fig. 4 a. Desmopsis talamancana G.E.Schatz \& Maas. Fruiting branch. - b. Desmopsis uxpanapensis G.E.Schatz. Flowering branch. - c. Desmopsis wendtii G.E.Schatz. Flowering branch (a: Aguilar \& Jiménez Madrigal 4317, type, U; b: Wendt et al. 4838, MO; c: Wendt et al. 4053, type, WIS).

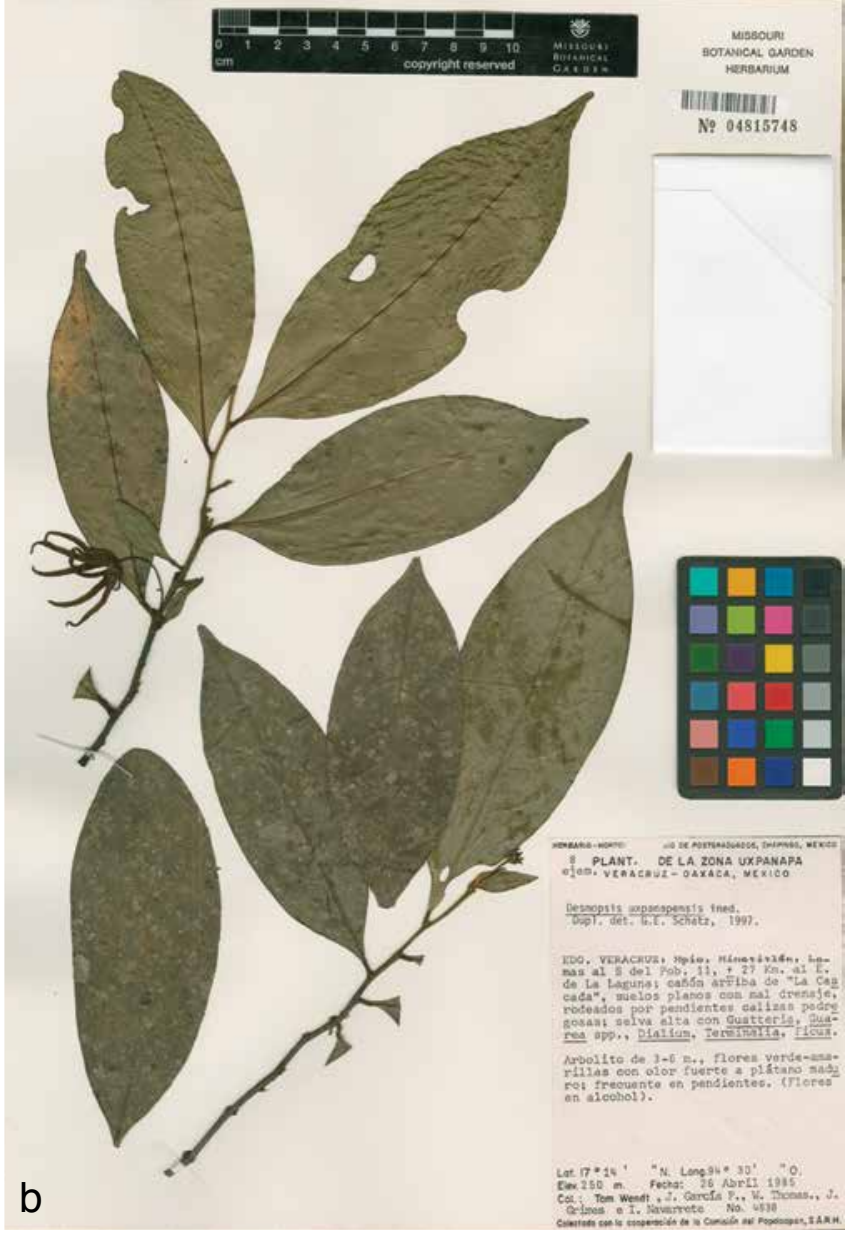

Tree or shrub 1.5-6 m tall, c. $10 \mathrm{~cm}$ diam; young twigs and petiole densely covered with erect, long-persisting hairs to c. $1 \mathrm{~mm}$ long. Leaves: petiole 3-7 mm long, 1-2 mm diam; lamina elliptic to ovate or narrowly so, $6-15$ by $2-6 \mathrm{~cm}$, chartaceous, somewhat verruculose and shiny above, glabrous, but the primary vein often covered with erect hairs above, densely covered with erect hairs (silvery white when young) to c. $1 \mathrm{~mm}$ long below, base acute to obtuse, apex acute, primary vein impressed to flat above, secondary veins 7-10 on either side of primary vein, slightly raised above, tertiary veins flat to slightly raised above, reticulate. Inflorescence and flower indument: pedicels and outer side of bracts, sepals, and petals densely covered with erect hairs, but outer side of petals sometimes less densely covered with appressed hairs. Inflorescences 1-3-flowered, leaf-opposed; flowering and fruiting pedicels $10-50 \mathrm{~mm}$ long, $0.5-1 \mathrm{~mm}$ diam; basal bract usually leafy, broadly ovate-triangular, $2-15$ by $3-15 \mathrm{~mm}$, upper bract scale-like, broadly ovatetriangular, $1-3$ by $2-3 \mathrm{~mm}$; sepals broadly ovate-triangular, 2-4 by 3-4 $\mathrm{mm}$, spreading to reflexed; petals yellow to white, the inner ones pale red at the base, subequal, narrowly ovatetriangular, $8-15$ by $3-4 \mathrm{~mm}$, margins revolute. Monocarps c. 5 , green, maturing red, spherical to ellipsoid, $9-25$ by $9-13 \mathrm{~mm}$, sparsely covered with appressed hairs, soon glabrous, apex rounded, slightly constricted between the seeds upon drying, wall $0.2-0.5 \mathrm{~mm}$ thick, stipes $2-3 \mathrm{~mm}$ long, c. $1 \mathrm{~mm}$ diam. Seeds 1-4, in one row, spherical to subspherical, discoid or hemispherical, $8-9$ by $5-8 \mathrm{~mm}$, slightly grooved.

Distribution - Mexico (Oaxaca, Veracruz).

Habitat \& Ecology — In evergreen to semi-evergreen to deciduous forest. At elevations of $0-1274 \mathrm{~m}$. Flowering: February to May, October, December; fruiting: March, May, October.

Vernacular names - Not recorded. 
Note - Desmopsis trunciflora is very well characterized among the species from Mexico by a dense indument of erect, long-persisting hairs on most parts of the plant. In the youngest leaves this indument is almost silvery coloured. In addition, the relatively low number of monocarps (c. 5) are borne on short stipes (2-3 mm long).

\section{Desmopsis uxpanapensis G.E.Schatz, sp. nov. - Fig.} 4b; Map 5

Desmopsis uxpanapensis is recognized by its young twigs and petiole densely covered with long-persisting, brownish, erect hairs, its pedicels (15-40 mm long) usually bearing a leafy basal bract, its relatively large sepals (6-12 by $3-4 \mathrm{~mm}$ ), and equal, narrowly triangular to linear petals (15-50 by $3-8$ mm). - Type: Schatz \& Wendt 977 (holo MEXU; iso CHAPA, F, MO, NY, U, WIS, XAL), Mexico, Veracruz, Mun. Jesus Carranza, Zona Uxpanapa, 2 km $\mathrm{N}$ of Poblado, 120 m, 13 Apr. 1984

Tree or shrub 1.5-8 $\mathrm{m}$ tall, diam not recorded; young twigs and petiole densely covered with long-persisting, brownish, erect hairs to c. $0.5 \mathrm{~mm}$ long. Leaves: petiole $5-10 \mathrm{~mm}$ long, 1-2 $\mathrm{mm}$ diam; lamina narrowly elliptic, $10-20$ by $3-8 \mathrm{~cm}$, chartaceous, shiny and glabrous above, except for some hairs along primary vein, sparsely covered with appressed hairs to glabrous below, base attenuate to acute, sometimes obtuse, apex acuminate (acumen 5-20 mm long), sometimes acute, the extreme tip obtuse, primary vein impressed above, secondary veins $6-8$ on either side of primary vein, raised above, tertiary veins raised above, reticulate. Inflorescence and flower indument: pedicels and outer side of bracts, sepals, and petals rather densely covered with appressed to erect hairs to subglabrous. Inflorescences 1- or 2-flowered, leaf-opposed; pedicels $15-40 \mathrm{~mm}$ long, c. $0.5 \mathrm{~mm}$ diam, to c. $2 \mathrm{~mm}$ diam in fruit; basal bract scale-like to usually leafy, ovate-triangular to narrowly so, 4-30 by 3-17 $\mathrm{mm}$, upper bract scale-like or rarely somewhat leafy, $1-6$ by $1-3 \mathrm{~mm}$; sepals narrowly triangular, $6-12$ by $3-4$ $\mathrm{mm}$, spreading to reflexed; petals yellowish green to yellow, equal, narrowly triangular to linear, $15-50$ by $3-8 \mathrm{~mm}$, margins revolute. Monocarps $8-15$, green, to orange, maturing dark purple, spherical to ellipsoid, $10-17$ by $7-15 \mathrm{~mm}$, glabrous, apex rounded, not constricted between the seeds upon drying, wall $0.2-0.5 \mathrm{~mm}$ thick, stipes $5-13 \mathrm{~mm}$ long, c. $1 \mathrm{~mm}$ diam. Seeds $1-3$, in one row, subspherical, discoid or hemispherical, $7-10$ by $4-6 \mathrm{~mm}$, grooved, slightly pitted.

Distribution - Mexico (S part of Veracruz).

Habitat \& Ecology — In medium to tall evergreen to semievergreen forest in deeper soil pockets within karstic limestone. At elevations of 100-250 m. Flowering: January to May, October; fruiting: February to April, July, October.

Vernacular name - Mexico: Anonacia.

Field observations - 'Flowers fruity fragrant' (Schatz \& Wendt 977, 980, 981, Mexico); 'flores con olor fuerte a plátano Maduro' (Wendt et al. 4827, 4838, Mexico).

Other specimens examined. Mexıco, Veracruz, km 0-1 del camino plan de Arroyos-Alvaro Obregon, 140 m, Dorantes et al. 2895 (F, MEXU, MO, U, $\mathrm{XAL}$ ); 0-2 km S del Campo Cedillo-Rumbo a Río Alegre, $140 \mathrm{~m}$, Dorantes et al. 2932 (F, U, WIS, XAL); km 0-3 camino Plan de Arroyo-Río Alegre, 140 m, Dorantes et al. 3069 (XAL 2 sheets); km 3-5 camino a Río Alegre, 150 m, Dorantes et al. 3653 (XAL); camino Cedillo Carolino Maya, 150 m, Dorantes et al. 4170 (XAL); camino a Obregon a $5 \mathrm{~km}$ del Campamento Hnos. Cedillos, $150 \mathrm{~m}$, Juan \& Avendano 34 (BM, MO, XAL 2 sheets); vicinity of Campamento La Laguna, $100 \mathrm{~m}$, Nee et al. 29732 (F, MO, WIS, XAL); $3 \mathrm{~km}$ SW of Campamento La Laguna, $100 \mathrm{~m}$, Nee 30016 (F, K, MO, PRA, U, US, WIS, XAL); 3 km del Campamento Hnos. Cedillos, $150 \mathrm{~m}$, Ortiz 85 (F, MEXU 2 sheets, US, XAL); Zona Uxpanapa, $2 \mathrm{~km} \mathrm{~N}$ of Poblado, $120 \mathrm{~m}$, Schatz \& Wendt 977 (MO, WIS), 980 (CHAPA, MO, WIS, XAL), 981 (CHAPA, MO, WIS, XAL); 2 km N del Poblado 2, Ejido F.J. Mina, $120 \mathrm{~m}$, Vázquez et al. 2461 (MO), 2618 (MO), Villalobos et al. 15 (CHAPA, MO, WIS); $2 \mathrm{~km}$ al $\mathrm{N}$ de Uxpanapa (Pob. 12) en camino al Pob. 13, $150 \mathrm{~m}$, Wendt et al. 4827 (MO); Lomas al S del Pob. 11, c. 27 km. al E. de La Laguna, cañón arriba de 'La Cascada', 250 m, Wendt et al. 4838 (MO).
Note - Desmopsis uxpanapensis is readily recognized by its young twigs and petiole densely covered with long-persisting, brownish, erect hairs to c. $0.5 \mathrm{~mm}$ long, its pedicels (15-40 $\mathrm{mm}$ long) usually bearing a leafy basal bract, its relatively long, narrowly triangular sepals (6-12 $\mathrm{mm}$ long), and monocarps with $1-3$ seeds in a single row.

\section{Desmopsis verrucipes Chatrou, G.E.Schatz \& N.Zamora - Map 4}

Desmopsis verrucipes Chatrou, G.E.Schatz \& N.Zamora in Erkens et al. (2006) 216, t. 4. - Type: Chatrou, Oosterhof \& Aguilar 102 (holo U; iso $\mathrm{CR}$, INB, MO), Costa Rica, Puntarenas, Cantón Osa, $5 \mathrm{~km}$ from Bahia Chal, near mouth of Río Rincón, 50 m, 29 Nov. 1998.

Tree or shrub 3-8 $\mathrm{m}$ tall, 2-4 cm diam; young twigs and petiole glabrous. Leaves: petiole 5-20 mm long, 1-3 mm diam; lamina narrowly elliptic, sometimes elliptic, $16-40$ by $5-17$ $\mathrm{cm}$, chartaceous, densely verruculose and shiny on both sides, glabrous above, glabrous below, but primary vein sometimes covered with some appressed hairs, base acute, rarely obtuse or attenuate, apex acuminate (acumen 5-20 mm long), primary vein slightly impressed above, secondary veins $7-14$ on either side of primary vein, raised above, tertiary veins flat to slightly raised above, reticulate to somewhat percurrent. Inflorescence and flower indument: pedicels and outer side of bracts, sepals, and petals sparsely covered with appressed hairs to glabrous. Inflorescences 1-6-flowered perennating contracted rhipidia bearing 1 flower at a time, leaf-opposed or often produced from the main trunk; pedicels $10-40 \mathrm{~mm}$ long, c. $1 \mathrm{~mm}$ diam, 1-4 $\mathrm{mm}$ diam in fruit; basal bract usually scale-like or rarely leafy, $1-8$ by $1-4 \mathrm{~mm}$, upper bract scale-like, broadly ovatetriangular, 1-4 by 2-4 $\mathrm{mm}$; sepals white with pink to red base, maturing red in fruit, ovate-triangular, $6-20$ by $4-10 \mathrm{~mm}$, distinctly veined; petals greenish yellow to white, subequal, narrowly triangular, $15-35$ by $5-9 \mathrm{~mm}$. Monocarps $5-40$, green, yellow, orange, maturing red, ellipsoid-oblongoid to spherical, $8-30$ by $8-15 \mathrm{~mm}$, sparsely covered with appressed hairs, soon glabrous, apex rounded, sometimes slightly constricted between the seeds upon drying, wall $0.3-0.5 \mathrm{~mm}$ thick, stipes 5-20 mm long, 1-2 mm diam. Seeds 2-7, in one row, discoid or hemispherical, $8-11$ by $2-3 \mathrm{~mm}$, slightly grooved, pitted.

Distribution - Costa Rica, Panama.

Habitat \& Ecology — In primary or secondary forests. At elevations of $0-500 \mathrm{~m}$. Flowering: January, February and August to November; fruiting: August to January.

Vernacular names - Not recorded.

Field observations - 'Flowers visited by small beetles' (Neill 5049A, Costa Rica).

Note - Desmopsis verrucipes is recognizable by its shiny, large leaves ( $16-40$ by $5-17 \mathrm{~cm}$ ) and large, persistent sepals of up to $20 \mathrm{~mm}$ long.

\section{Desmopsis wendtii G.E.Schatz, sp. nov. — Fig. 4c; Map 8}

Desmopsis wendtii is recognized by its strictly trunciflorous inflorescences, relatively long pedicels (30-50 mm long) bearing scale-like basal and upper bracts, unequal petals, the inner petals narrower, and 12-17 ovules in two rows. - Type: Wendt et al. 4053 (holo CHAPA; iso MEXU, MO, NY, U, WIS, XAL), Mexico, Veracruz, Mun. Minatitlán, 12 km NE of Uxpanapa, along road to Díaz Ordaz, loma SW of Díaz Ordaz and NW of Poblado, 200 m, 13 May 1983.

Tree 10-14 m tall, 25-40 cm diam; young twigs sparsely covered with appressed hairs, soon glabrous. Leaves: petiole 7-15 $\mathrm{mm}$ long, 1-3 $\mathrm{mm}$ diam; lamina oblong-elliptic to oblongobovate, $10-30$ by $3-10 \mathrm{~cm}$, chartaceous, shiny and glabrous above, glabrous below, base acute, apex acuminate (acumen $5-15 \mathrm{~mm}$ long), primary vein impressed above, secondary veins 
8-12 on either side of primary vein, raised above, tertiary veins raised above, reticulate. Inflorescence and flower indument: pedicels and outer side of bracts, sepals, and petals sparsely covered with appressed hairs to glabrous. Inflorescences 1-3flowered, borne on the main trunk from near the base to $2 \mathrm{~m}$ high; pedicels $30-50 \mathrm{~mm}$ long, c. $1 \mathrm{~mm}$ diam; basal and upper bracts scale-like, broadly ovate, 1-2 mm long; sepals broadly ovate, $3-6$ by $3-6 \mathrm{~mm}$, spreading; petals greenish yellow to yellow, with a red blush inside at the base at anthesis, unequal, outer petals elliptic to ovate, $20-30$ by $8-14 \mathrm{~mm}$, inner ones oblong-elliptic, $24-25$ by $7-9 \mathrm{~mm}$; carpels $5-10$, ovaries $2-2.5$ $\mathrm{mm}$ long, densely covered with appressed, silvery hairs, stigma spherical to obpyriform, c. $1 \mathrm{~mm}$ diam, sparsely covered with appressed hairs, ovules 12-17, in two rows. Monocarps and seeds unknown.

Distribution - Mexico (Veracruz).

Habitat \& Ecology - In tropical wet forest with Acacia usamacintensis, Brosimum sp., Compsoneura sprucei, Dialium sp., Guarea sp., Guatteria grandiflora, Pouteria sapota, Terminalia sp., Zuelania sp., etc. At an elevation of c. 200 m. Flowering: April, May; fruiting: not known.

Vernacular names - Not recorded.

Field observations - 'Flowers with a fragrance of ripe banana, with an element of formalin' (Wendt et al. 4053, Mexico).

Other specimens examined. Mexıco, Veracruz, Mun. Minatitlán, 12 km NE of Uxpanapa, along road to Díaz Ordaz, loma SW of Díaz Ordaz and NW of Poblado, 200 m, Schatz \& Wendt 988 (MEXU, MO, WIS).

Note - The strictly trunciflorous habit distinguishes $D$. wendtii. The flower closely resembles those of the genus Guatteria, which, however, possess a single basal ovule, imbricate petals, and axillary inflorescences. The biseriate condition of the ovules is shared with a number of species from Costa Rica including $D$. biseriata (also from Panama), D. heteropetala, and $D$. talamancana.

Acknowledgements We are indebted to the curators of the following herbaria, from which we borrowed or studied material: B, BM, BR, C, CAS, CHAPA, CR, DUKE, F, FHO, G, GH, HUA, INB, INIREB, JAUM, L, LL, MEXU, MICH, MO, NY, P, PMA, RB, S, STRI, TEX, U, UC, US, W, WAG, WIS, WU, $X A L, Z$. The distribution maps in this publication were created using ESRIs ArcMap software for Windows. The first author acknowledges support for field work from an NSF Doctoral Dissertation Improvement Grant BSR8511373, the George H.M. Lawrence Memorial fund, the E.K. and O.N. Allen Herbarium Fund of the University of Wisconsin, Madison, the University of Wisconsin, Madison Natural History Museums Council, and the Davis Fund of the University of Wisconsin, Madison Botany Department. He is especially thankful for the mentorship and inspiration provided by the late H.H. Iltis

\section{REFERENCES}

Baillon H. 1868. Mémoire sur la famille des Anonacées. Adansonia 8: 162184.

Chaowasku T, Thomas DC, Van der Ham RWJM, et al. 2014. A plastid DNA phylogeny of tribe Miliuseae: Insights into relationships and character evolution in one of the most recalcitrant clades of Annonaceae. American Journal of Botany 101 (4): 691-709.
Chatrou LW, Pirie MD, Erkens RHJ, et al. 2012. A new subfamilial and tribal classification of the pantropical flowering plant family Annonaceae informed by molecular phylogenetics. Botanical Journal of the Linnaean Society 169: 5-40.

Croat TB. 1978. Flora of Barro Colorado Island: 401. Stanford, Stanford University Press.

Erkens RHJ, Maas PJM, Chatrou LW, et al. 2006. Seven taxonomic discoveries in Annonaceae from south-eastern Central America. Blumea 51: 199-220.

Fries RE. 1900. Beiträge zur Kenntniss der Süd-Amerikanischen Anonaceen. Kongliga Svenska Vetenskapsakademiens Handlingar, n.s., 34 (5): 1-59.

Fries RE. 1927. Die von Ekman in Westindien gesammelten Anonaceen. Arkiv för Botanik 21A, 9: 1-25.

Fries RE. 1930. Revision der Arten einiger Anonaceen-Gattungen I. Acta Horti Bergiani 10, 1: 1-128.

Fries RE. 1931. Revision der Arten einiger Anonaceen-Gattungen II. Acta Horti Bergiani 10, 2: 129-341, pl. 1-27.

Fries RE. 1941. Neue amerikanische Annonaceen. Acta Horti Bergiani 13 3: 103-116.

Fries RE. 1948. New or noteworthy Annonaceae from tropical America. Kongliga Svenska Vetenskapsakademiens Handlingar, ser. 3, 24, 10: 3-19.

Fries RE. 1959. Annonaceae. In: Melchior H (ed), Die natürlichen Pflanzenfamilien ... begründet von A. Engler und K. Prantl, ed. 2, Band 17a II: 1-171. Duncker \& Humblot, Berlin.

Grisebach AHR. 1866. Catalogus plantarum cubensium: 2-4. Engelmann, Leipzig.

Hemsley WB. 1878. Diagnoses plantarum novarum vel minus cognitarum Mexicanarum et Centrali-Americanarum 1: 1-2. Taylor \& Francis, London. Hooker WJ. 1841. In: Icones Plantarum pl. 328. Longman, Orme, Brown, Green \& Longmans, London.

Jiménez-Ramírez J, González-Martínez CA. 2016. Una nueva especie de Desmopsis (Annonaceae) endémica de Guerrero, México. Brittonia 68, 1: $51-54$.

Kuntze O. 1891. Revisio generum plantarum, Pars 1: 7-8. Arthur Felix, Leipzig.

Lundell CL. 1939. Studies of Mexican and Central American plants. Lloydia 2: $85-87$.

Lundell CL. 1974. Studies of American plants - VI. Wrightia 5, 2: 23-29.

Maas PJM, Mennega EA, Westra LYT. 1994. Studies in Annonaceae XXI. Index to species and infraspecific taxa of neotropical Annonaceae. Candollea 49: 389-481.

Ortiz-Rodriguez AE, Ruiz-Suarez E, Ornelas JF. 2016. Phylogenetic relationships among members of the neotropical clade of Miliuseae (Annonaceae): generic non-monophyly of Desmopsis and Stenanona. Systematic Botany 41: 815-822.

Richard A. 1841 '1845'. In: De la Sagra R, Histoire Physique, Politique et Naturelle de L'lle de Cuba: 44

Robinson BL, Greenman JM. 1895. Miscellaneous new species. American Journal of Science 50: 175.

Safford WE. 1916. Desmopsis, a new genus of Annonaceae. Bulletin of the Torrey Botanical Club 43: 183-193.

Schatz GE, Maas PJM. 2010. Synoptic revision of Stenanona (Annonaceae). Blumea 55: 205-223.

Schatz GE, Maas PJM, Maas-van de Kamer H, et al. 2018. Revision of the Neotropical genus Sapranthus (Annonaceae). Blumea 63: 54-66.

Standley PC. 1932. New plants from British Honduras. Field Museum of Natural History, Botanical series 11: 130-131.

Standley PC, Steyermark JA. 1944. Studies of Central American plants - VI. Field Museum of Natural History, Botanical series 23, 4: 156-157.

Von Schlechtendal DFL, Von Chamisso A. 1831. Plantarum mexicanarum a cel. viris Schiede et Deppe collectarum, recensio brevis. Linnaea 6: 417-418.

Woodson RE, Schery RW. 1941. Contributions towards a flora of Panama. V. Annals of the Missouri Botanical Garden 28: 427-429. 


\section{IDENTIFICATION LIST}

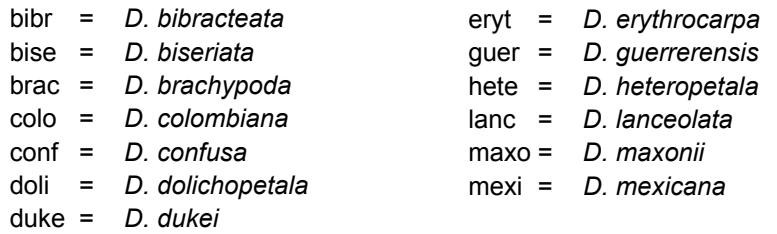

Acosta 658: bibr; 757: bibr; 1025: schi; 2284: maxo; 2662; hete; 3372: bibr - Aguilar 96: maxo; 301: hete; 470: hete; 478: hete; 482: hete; 529: verr; 559: hete; 629: conf; 2435: verr; 2712: micr; 4317: tala; 5274: verr; 7577: micr; 10771: hete; 11132: verr; 11411: verr - Aizprúa B1303: pana; B4272: maxo - Alfaro V. 1084: sp. indet.; 1833: maxo; 1936: conf; 4572: schi - Alvarado 29: maxo; 107: sp. indet. - Alvarado-Cárdenas 597: lanc - Alverson 1833: micr; 1981: bibr; 2577: micr - Alzate 1070: duke; 1258 : duke - Angulo 162: maxo - Antonio 1753: maxo; 2074: schi; 3140: bise; 4850: nigr-Aranda 2861: schi-Araquistain 2488A: schi; 2513: schi; 2778 : schi; 3125: schi; 3277: schi - Arcizia 159: duke - Atha 1168: eryt - Ayala 1099: bibr; 1124: bibr.

Bailey 507: pana - Baker s.n. (R1): bibr - Barringer 1635: conf; 2490: micr - Batista 304: nigr - Bawa 584: micr; 704: micr - Beaman 6335: subn - Bello 375: micr; 471: micr; 604: micr; 1060: schi; 1151: schi; 1562: sp. indet. - Blum 2325: pana - Boyle 1390: micr; 7141: micr - Brand 48: duke; 61: duke; 138: duke; 912: duke; 1063: duke - Brenes 3898: micr; 4279: micr; 6629: bibr; 12663: schi; 13607: micr; 14928: bibr; 15591: bibr; 19152: bibr; 19153: bibr - Brewer 190: eryt; 266L eryt; 1151: eryt; 1235: eryt; 5653: eryt - Burger 4324: micr; 4446: conf; 4468: conf; 4492: conf; 4539: conf; 9023: hete; 9180: bibr; 10467: micr; 11242: micr; 12124: micr; 12383: hete - Busey 650: conf.

Calderon 314: bibr - Callejas 5723: schi - Calzada 280: subn; 773: subn; 8118: subn - Cárdenas 815: duke; 855: duke; 859: duke; 863: duke; 2083 : duke; 2272: duke - Carrion 239: maxo - Cascante 186: bibr - Castillo 621: subn; 630: subn - Cedillo T. 7: subn; 10: subn; 256: subn; 287: subn; 1650: trun; 2832: subn; 2845: subn - Cerda 156: micr - Chacón, A. 349: maxo; 369: conf - Chacón, I. 496: micr; 533: micr; 782: micr; 937: micr; 953: micr - Chatrou 45: hete; 53: micr; 85: micr; 88: micr; 94: schi; 96 : micr; 98: micr; 102: verr; 115: verr - Chavarría 71: micr; 2291: bibr; 2298: bibr - Chaves 272: micr; 338: micr; 1504: micr - Chávez 31: schi; 288: bibr; 325: bibr; 406: bibr; 532: micr - Cházaro B. 383: subn; 415: subn; 6627 : trun - Chinchilla 217: maxo - Churchill 4366: pana; 4367: pana - Clewell 4205: schi - Cogollo 477: colo; 507: colo; 741: colo; 893: colo; 1080: colo; 1220: colo; 1438: colo; 1469: colo - Conrad 2772: schi - Contreras 5912: eryt; 5976: eryt; 6727: eryt; 6809: eryt; 7808: eryt; 7816: eryt; 8973: eryt; 10186: eryt - Cook 567: schi - Cooper 47: verr; 53: verr - Coronado 1134: schi; 1883: schi; 1978: schi; 2038: schi; 2175: schi; 2324: schi; 2528: schi; 2637: schi; 2700: schi; 2857: schi; 4305: schi; 4644: schi; 4888: schi; 5822: bibr - Correa A. 293: maxo; 1822: nigr; 7600: maxo; 7762: maxo; 8172: maxo; 8580: maxo; 9246: maxo; 9323: maxo; 9536: maxo; 10000: maxo; 10239: maxo; 10783: maxo; 11393: maxo; 11490: maxo - Croat 244: schi; 6463: pana; 6764: pana; 7361: pana; 7373: pana; 7980: pana; 8793: pana; 8987: pana; 9411: pana; 9437: pana; 10878: pana; 14698: maxo; 16414: bise; 22234: conf; 34104: nigr; 36464: schi; 44378: conf; 49037: maxo; 66308: maxo; 66322: conf; 77136: pana - Cuevas 6545: sp. indet.

D'Arcy 3938A: pana; 10833: conf; 14537: pana; 16007: maxo-Daubenmire 633: bibr - Davidse 23479: bibr; 23556: nigr; 24333: maxo; 24389: maxo; 28462: maxo; 30925: micr; 32156: eryt - Davidson, C. 6837: micr; 8836: micr - Davidson, M. 527: maxo - De Gracia 779: nigr - De Nevers 4338: nigr; 5281: nigr; 7976: nigr - Deago 196: conf; 199: conf - Döbbeler 608: bibr - Dorantes 2895: uxpa; 2932: uxpa; 3069: uxpa; 3653: uxpa; 4170: uxpa - Dressler 3546: maxo - Dryer 1350: micr - Duke 252: pana; 4822: pana; 5266: duke; 6126: pana; 8286: pana; 8777: duke; 8798: duke; 9917 : duke; 13184: nigr; 15278: nigr - Dwyer 524: maxo; 4516: maxo; 7876: pana. Ebinger 177: pana; 223: pana - Edwards P-443: schi - Ekman 17499: negl; 17753: negl - Emeterio 409: schi - Espinosa 5711: nigr; 5963: nigr; 6127: conf - Espinoza 9: schi; 11: sp. indet.; 162: bibr; 745: bibr; 2807 : schi - Estrada 168: bibr.

Fernández 386: maxo; 405: hete; 1729: bibr - Fletes 198: maxo - Flores 94: micr - FLORPAN 1156: pana; 2122: pana; 3283: maxo; 5915: maxo; 6430: maxo - Folsom 1676: pana; 1688: pana; 3158: maxo; 5921: maxo; 6236: pana; 6437: schi; 6512: maxo; 6943: maxo; 7190: maxo; 9192: micr - Fonseca 23: verr - Foster 761: pana; 830: pana; 1336: pana; 1694: nigr; 2082: maxo; 2314: pana; 15771: maxo - Friedrichsthal 1176: bibr - Fuentes 353: micr; 417: micr.

Galdames 3472: maxo; 5192: pana; 5354: schi - Galeotti 4606: subn; 7083: trun - Gallardo 28: micr - Gamboa 2156: maxo - Garwood 479: bibr; 735 :

$\begin{aligned} \text { micr } & =D \cdot \text { microcarpa } \\ \text { negl } & =D \cdot \text { neglecta } \\ \text { nigr } & =D \cdot \text { nigrescens } \\ \text { oers } & =D . \text { oerstedii } \\ \text { pana } & =D . \text { panamensis } \\ \text { schi } & =D . \text { schippii }\end{aligned}$

$\begin{aligned} \text { subn } & =D . \text { subnuda } \\ \text { tala } & =D . \text { talamancana } \\ \text { trun } & =D . \text { trunciflora } \\ \text { uxpa } & =D . \text { uxpanapensis } \\ \text { verr }= & D . \text { verrucipes } \\ \text { wend }= & D . \text { wendtii }\end{aligned}$

micr; 763: bibr; 958: micr; 1674A: pana; 1941A: pana - Gentry 2674: pana; 2842: pana; 3182: pana; 3192: pana; 3240: pana; 3251: pana; 3256: pana; 3284: pana; 3301: pana; 3308: pana; 3373: pana; 4835: pana; 4844: pana; 5773: maxo; 6294: pana; 7130: pana; 8681: pana; 43909: schi; 71653: micr; 78726: hete - Gillis 10149: conf - Gómez P. 18132: conf; 21968: conf; 24090: schi; 24132: bise - Gómez-Laurito 8744: micr; 8808: duke; 11481: micr; 11599: sp. indet.; 11908: micr; 11925: conf - González 431: conf González R. 1082: maxo; 1684: micr; 4348: hete - González-Martinez 40: guer; 892: guer - Grayum 4763: verr; 5658: conf; 5814: bise; 6102: bibr; 6251: bibr; 7700: micr; 8009: micr; 8906: bise; 8913: verr; 9272: conf; 11470: bibr - Grijalva P. 27: schi; 271: schi; 413: schi; 3776: schi - Guerra 667: maxo - Gutierrez 27: micr.

Haber 1712: schi; 1713: schi; 2681: micr; 4750: micr; 4769: micr; 4774: micr; 4821: schi; 4824: schi; 4847: micr; 4917: micr; 4958: micr; 6080: micr; 7871: bibr; 8043: micr; 8269: bibr; 9288: bibr; 9765: bibr; 10962: bibr; 11578: schi; 11959: micr - Hamilton 2940: nigr - Hammel 1277: pana; 4433: nigr; 9262: micr; 10809: micr; 11232: micr; 11678: schi; 12164: micr; 12389: schi; 13259: schi; 16102: pana; 16912: hete; 17556: bise; 17908: sp. indet.; 18366: hete; 18700: bibr - Hampshire 781: lanc - Harmon 93: schi; 344: schi - Hartman 12180: duke - Hartshorn 1098: micr; 1272: micr; 2253: schi - Hatheway 1453: bibr - Hayes 468: pana - Hazlett 5038: maxo; 5068: conf - Hensold 1009: bibr - Hernández 663: bise - Hernández G. 116: subn; 598: subn; 739: subn; 780: subn; 930: subn; 996: subn; 1053 : subn - Herrera, H. 673: pana; 843: schi; 920: pana; 922: pana - Herrera Ch. 169: micr; 358: micr; 522: micr; 855: micr; 1142: micr; 1424: micr; 1429: micr; 2066: schi; 2535: sp. indet.; 3107: micr; 3498: tala; 4310: verr; 4416: hete; 4694: conf; 6353: schi; 7802: micr - Herrera P. 94: schi - Hinton 15823: mexi; 15836: mexi - Hladik 70: pana - Hodge 7040: schi - Holl 1078: maxo - House 2047: schi - Hurtado 109: hete.

Ibáñez G. 2418: pana; 4260: pana - Ibarra 3369: subn - INBio I 212: schi - INBio II 51: schi; 99: schi - Ishiki 2310: trun.

Jacobs 2915: micr; 2995: micr - Janzen 10335: bibr; 11768: bibr; 12135 bibr; 12147: bibr - Jiménez, A. 156: bibr - Jiménez, O. 416: bibr - Jiménez Madrigal 744: schi; 813: hete; 955: bibr; 1145: bibr - Jiménez Muñoz 1949: micr; 3515: bibr; 3541: bibr - Johnston 1672: pana; 1726: pana; 1744: pana - Juan 34: uxpa.

Kennedy 336: maxo - Kenoyer 650: pana - Kernan 282: verr; 801: verr; 845: verr; 870: verr; 1299: hete-Knapp 935: pana; 1583: conf; 2202: verr; 2299: maxo; 3493A: schi; 3927: pana; 5899: nigr - Koptur 119: micr-Kovar 1070: bibr - Kress 94-3246: maxo; 94-3906: maxo - Kriebel 3: conf.

Laguna 136: schi - Lallathin 5055: maxo - Lankester 1323: bibr - Las Cruces Tropical Botanical Garden 74-225: conf - Lawton 1184: micr - Lent 3331: micr - León 487: duke - Lépiz 58: hete - Liebmann 1: trun; 4: subn; 5: trun; 6(152): trun; 7: trun; 9: trun; 10: trun; 154(19): subn - Liesner 524: maxo; 1038: nigr; 14104: schi; 14723: micr; 15117: bibr - Linden 982: trunc-Little 25171: schi; 25180: schi - López Cruz 534: lanc - Lot 1801: trun - Luna 4265: schi - Lundell 20660: eryt - Luteyn 1810: maxo; 4659: nigr.

Maas 728: maxo; 7839: veru; 9401: schi; 9461: oers; 9540: schi; 9547: maxo; 9550: maxo; 10483: colo - MacDougall 3338: schi - Marín 214: hete - Martínez, I. 88: bibr - Martínez, L. 1247: micr; 1354: nigr; 1432: micr - Martínez-Camilo 506: lanc-Matuda 2299: lanc; 16145: lanc; 17921: lanc - Maxon 5564: maxo - McCaffrey 159: bibr - McDade 871: pana McPherson 7448: maxo; 7924: maxo; 8013: conf; 8129: nigr; 8168: nigr; 10497: pana; 10499: pana; 10507: maxo; 11054: nigr; 11281: nigr; 12341 : maxo; 12355: maxo; 12549: sp. indet.; 19564: nigr; 20042: nigr; 20610 : nigr; 20636: nigr - Medina A. 225: trun; 842: trun - Monro 4692: brac; 4882: brac; 4904: brac - Monroy 117: trun - Mora V. 27: micr; 67: micr; 72: bibr; 239: conf - Moraga 68: schi - Morales, J. 549: lanc - Morales, J.F. 1411: micr; 1935: hete; 2055: oers; 4837: hete; 5421: oers; 6838: oers - Moran 4186: pana - Moreno 7604: schi; 17235: schi; 18848: bibr; 19108B: schi; 19113: schi; 19577: bibr; 19586: bibr; 19798: bibr; 20282: schi; 20572: schi; 23686: schi; 23786: schi; 28430: bibr - Mori 2462: maxo; 3013: nigr; 4179: maxo; 5317: maxo - Morris 1721: maxo-Mowbray 1337: micr; 1446: micr - Murphy 1228: conf; 1246: conf-Murray 842: micr; 1354: trunc; 1355: trun. Navarro V. 265: conf - Nee 9595: pana; 11582: maxo; 14106: bise; 23374: subn; 27898: schi; 28028: bibr; 28388: schi; 29732: uxpa; 30016: uxpa; 32869: trun; 32870: trun - Neill 291: schi; 1590: schi; 1735: schi; 1908 : sch; 3870: schi; 4114: schi; 4121: schi; 5049A; verr. 
Oersted 148: oers; 149: oers - Opler 556: bibr; 1700: micr; 1704: bibr Oppenheimer 66-11-2-1335: pana - Ortega O. 1912: subn - Ortíz 572: schi; 585: schi; 640: schi; 1943: schi - Ortíz D. 85: uxpa.

Palma G. 192: trun - Pascual 1812: trun; 2423: trun - Penneys 300: micr; 421: micr - Pennington 11524: micr - Pérez 690: maxo; 1349: micr; 1428: maxo; 1633: pana; 1664: maxo; 1758: pana; 1918: pana; 2380: maxo Pipoly 3907: schi; 3910: schi; 4777: schi; 4966: schi; 5011: schi; 5334 : schi; 5900: schi; 6010: schi; 6056: schi; 6159: schi; 6183: schi; 6185: schi; 6235: schi - Pittier 2269: pana; 2660: pana; 3154: maxo; 3367: bibr; 5747: bibr; 7967: hete; 16014: micr - Polanco 2336: micr; 2500: micr - Porter 4884: maxo - Pounds 289: micr - Poveda 3878: bibr - Prado G. 197-A: schi - Purpus 8862: trun; 16630: subn.

Quesada 276: schi.

Raven 20924: conf - Rentería A. 2745: colo - Reyes-García 1696: lanc Ríos 38: schi - Rivera G. 646: bibr; 967: bibr; 989: schi; 1135: bibr; 1764 : bibr; 2366: verr - Rivera N. 321: conf - Robbins 5871: schi - Robles 1481: micr; 1540: micr; 1945: micr; 2231: micr; 2608: micr; 2651: micr - Robleto T. 339: bibr; 352: bibr; 923: bibr; 1085: bibr; 2125: schi - Rodríguez 244: bibr - Rodríguez G. 587: schi; 2277: micr; 2826: bibr; 4244: bibr; 4966: hete; 5009: schi; 5010: micr; 5826: bibr; 8116: hete; 11801: maxo-Romero C. 6133: duke - Roubik 659: maxo - Rueda 2685: micr; 3779: schi; 3977: schi; 4266: schi; 4267: schi; 4927: schi; 4956: schi; 4972: schi; 5233: schi; 5271: schi; 5553: schi; 5594: schi; 5804: schi; 5894: schi; 6058: micr; 6105: schi; 6311: schi; 6461: schi; 6521: schi; 6638: schi; 7562: schi; 7573: chi; 7576: schi; 7640: schi; 7645: schi; 7781: schi; 7897: schi; 7918: schi; 8725: schi; 9283: micr; 9379: micr; 9475: schi; 9529: schi; 9720: schi; 9837: schi; 9885: schi; 10525: schi; 14148: schi; 14216: schi; 15308: schi; 16418: schi; 16685: bibr; 16803: schi; 16974: micr; 17066: micr; 17788: micr; 17911: micr - Ruíz 355: maxo

Saborío 26: maxo - Salas M. 7367: trun - Salick 8046: micr - Salvador 71: subn - Sánchez G. 357: schi - Sandino 520: bibr; 3349: schi; 4115: bibr; 4150: bibr; 4244: bibr; 4497: schi; 4648: schi; 4662: schi; 4743: schi Santamaría A. 3125: hete; 5395: bibr; 7708: brac - Santamaria E. 1034: schi - Saunders 1079: schi; 1079B: schi; 1234: schi - Schatz 977: uxpa; 980: uxpa; 981: uxpa; 988: wend; 1001: conf; 1030: schi; 1059: micr; 1061: conf; 1073: pana; 1087: bibr; 1191: subn; 1208: pana - Schiede 1287: trun - Schipp 960: schi - Schmalzel 1431: bibr - Schubert 1048: schi - Sessé y
Lacasta 2323: trun; 2324; trun; 2325: trun - Shank 4543: micr; 4727: schi 4758: schi - Shimek 232: bibr - Skog 4016: conf - Smith, A. F1918: micr; P2458: bibr; P2547: schi - Smith, D. 293: micr; 409: micr; 496: micr; 1218 micr - Solano 37: micr; 807: conf; 946: bibr; 1146: micr; 1419: micr; 1643 oers; 5817 : brac - Soto 242 : oers - Sousa 7142: lanc - Sperry 826: micr; 842: micr; 844: micr; 864: micr; 962: micr - Standley 27200: pana; 27454 pana; 31024: pana; 31337: pana; 36774: micr; 36834: micr; 36959: micr 40009: bibr; 40057: bibr; 41158: pana; 44208: bibr; 44444: schi; 44576 schi; 45027: bibr; 45176: schi; 45516: schi; 45663: bibr; 45857: schi; 45882 schi; 46113: bibr; 46177: micr; 46618: schi; 46622: bibr; 46641: schi; 48458 schi; 54182: schi - Stevens 4783: schi; 6430: schi; 6740: schi; 6809: schi; 6851: schi; 6862: schi; 7037: schi; 9610: schi; 11871: schi; 12103: schi; 12249: schi; 12631: schi; 12840: schi; 16529: schi; 23163: schi; 23914: micr; 24098: micr; 24556: micr; 29129: schi; 33290: schi - Steyermark 34304: lanc; 37331: lanc; 41543: lanc; 47354: lanc - Sytsma 1168: maxo; 2042: nigr; 2491: nigr; 3360: pana; 3449: pana; 3543: maxo.

Tate 4 (150): schi - Taylor 3536: conf; 3584: conf; 3595: maxo - Thomas 3671: lanc - Thomsen 197: verr; 1015: schi - Todzia 1709: verr - Tonduz 9188: micr - Toval 26: schi; 284 : schi.

Urbina 3201: schi - Utley 4030: schi.

Valdespino 432: nigr - Valerio 149: bibr; 231: bibr - Van der Werff 7085: maxo; 14012: micr; 22210: nigr - Vargas, L. 291: bibr; 782: bibr; 2239: bibr - Vargas, O. 251: micr - Vargas R. 1499: hete - Vasquez 71: uxpa - Vázquez T. 2461: uxpa; 2618: uxpa - Velasco-Sinaca 629-B: subn - Ventur 193 eryt - Villalobos C. 15: uxpa - Von Hagen 1380: schi - Von Wedel 279: micr; 694: schi; 1265: micr; 1459: micr; 1565: micr; 1767: micr; 2464: micr.

Walker 144: schi; 193: verr; 366: pana; 369: pana; 370: pana; 374: bibr; 385 micr; 386: micr; 389: micr; 390: schi; 399: micr; 401: schi; 402: schi; 408: bibr; 431: doli - Warscewicz 2 (or 226): bibr - Weber 6101: micr - Wendt 3806: subn; 4053: wend; 4827: uxpa; 4838: uxpa - Whitson 47: micr; 286 : micr; 488: micr; 511: micr - Wilbur 9787: schi; 33593: micr; 34378: micr; 34799: micr; 34803: micr; 37191: micr; 37235: micr; 37646: micr; 63175: micr; 63239: micr; 66104: micr; 66117: micr -Williams 23838: schi; 24545 bibr; 26523: bibr; 26645: bibr - Woodson 1864: schi; 1944: micr - Woodworth 367: pana - Wright 1: bibr; 1852: negl.

Yuncker 6155: doli.

Zamora 1911: verr; 2093: hete; 2339: micr; 4911: micr - Zapata 1817: maxo - Zetek 4336: pana - Zúñiga 78: micr; 287: hete; 476: oers.

\section{INDEX}

Accepted names are in roman type. New names are in bold type. Synonyms are in italics. The number after each name is the number of the species as used in this revision. References to pages are given in square brackets.

\author{
Annona bibracteata Hook. 22 \\ Asimina rhombifolia Griseb. 15 \\ Desmopsis Saff. [p. 68] \\ bibracteata (B.L.Rob.) Saff. 1 \\ biseriata G.E.Schatz \& Maas 2 \\ brachypoda G.E.Schatz \& Maas 3 \\ brevipes R.E.Fr. 19 \\ colombiana G.E.Schatz \& Maas 4 \\ confusa G.E.Schatz, N.Zamora \& Maas 5 \\ dolichopetala R.E.Fr. 6 \\ dukei G.E.Schatz 7 \\ erythrocarpa Lundell 8 \\ galeottiana (Baill.) Saff. [var. galeottiana] 22 \\ galeottiana (Baill.) Saff. var. subnuda R.E.Fr \\ 20 \\ glabrata Schery 14
}

\author{
Desmopsis (cont.) \\ talamancana G.E.Schatz \& Maas 21 \\ trunciflora (Schltdl. \& Cham.) G.E.Schatz 22 \\ uxpanapensis G.E.Schatz 23 \\ verrucipes Chatrou, G.E.Schatz \& N.Zamora \\ 24 \\ wendtii G.E.Schatz 25 \\ Guatteria bibracteata (Hook.) Hemsl. 22 \\ Trigynaea galeottiana Baill. 22 \\ Unona bibracteata B.L.Rob. 1 \\ panamensis B.L.Rob. 18 \\ Unonopsis galeottiana (Baill.) R.E.Fr. 22 \\ trunciflora (Schltdl. \& Cham.) R.E.Fr. 22 \\ Uvaria neglecta A.Rich. 15 \\ Xylopia trunciflora Schltdl. \& Cham. 22 \\ Xylopicrum trunciflorum (Schltdl. \& Cham.) \\ Kuntze 22
}

\section{LIST OF VERNACULAR NAMES}

Anona (eryt, schi)

Anonacia (uxpa)

Anonilla (eryt, pana)

Anono (schi)
Botín de reina (schi)

Cabo de Hacha (eryt)

Canjura (schi)

Flor de Guineo (bibr)
Guinea (bibr)

Palanca (schi)

Palanco (micr, schi)

Posa de los Indios (bibr)

Uva (micr) 